\title{
Inter-annual variability of Net Ecosystem Productivity for a temperate mixed forest: A predominance of carry-over effects?
}

\author{
Marc Aubinet $^{\mathrm{a}, *}$, Quentin Hurdebise ${ }^{\mathrm{a}}$, Henri Chopin ${ }^{\mathrm{a}}$, Alain Debacq ${ }^{\mathrm{a}}$, Anne De Ligne ${ }^{\mathrm{a}}$, \\ Bernard Heinesch ${ }^{\mathrm{a}}$, Tanguy Manise ${ }^{\mathrm{a}, \mathrm{b}}$, Caroline Vincke ${ }^{\mathrm{b}}$ \\ a TERRA Teaching and Research Centre, University of Liège - Gembloux Agro-BioTech, 2 Passage des Déportés, B-5030 Gembloux, Belgium \\ ${ }^{\mathrm{b}}$ Earth and Life Institute, Université catholique de Louvain, Louvain-la-Neuve, Belgium
}

\section{A R T I C L E I N F O}

\section{Keywords:}

Net Ecosystem Productivity

Eddy covariance

Interannual variability

Forest ecosystem

\begin{abstract}
A B S T R A C T
This study presents twenty years of Net Ecosystem Productivity estimations obtained using eddy covariance in a mixed forest, dominated by beech with sparse conifers, at the Vielsalm station, in the Belgian Ardennes.

First the quality and reliability of the data set is discussed. An uncertainty analysis showed that if, on one hand, the site heterogeneity and set-up changes may strongly affect yearly NEP estimates, questioning thus the total carbon budget relevance, on the other hand, robust inter-annual anomalies may be obtained as long as a site dedicated data treatment is carefully applied. A validation of the anomalies by comparison with a growth index derived from tree ring measurements is given. The resulting anomalies (range: $[-206 ;+123] \mathrm{g} \mathrm{C} \mathrm{m}^{-2}$ $\mathrm{yr}^{-1}$, standard deviation: $\left.93 \mathrm{~g} \mathrm{C} \mathrm{m}^{-2} \mathrm{yr}^{-1}\right)$ being larger than their own uncertainty $\left(\sim 30 \mathrm{~g} \mathrm{C} \mathrm{m}^{-2} \mathrm{yr}^{-1}\right), a^{2}$ inter-annual variability analysis is possible.

This analysis shows that the sources of NEP inter-annual variability at the Vielsalm station are multiple but the most prominent causes are biotic processes driven by carry-over effects of preceding meteorological events. The lowest observed NEP, in 2000, resulted from a bark beetle attack probably prompted by an early frost event in 1998. Besides, the robust lagged correlation between NEP anomalies and mean vapor pressure deficit during the preceding vegetation season also suggests a carry-over effect of water limitation during the previous year on the beech NEP. Mechanisms driving this carry-over effect are supposedly linked to tree physiology, which is confirmed by a dependency of canopy photosynthetic capacity to previous year water limitation. Some hypotheses, involving biomass allocation and bud formation, are proposed to explain its lagged impact on canopy photosynthetic capacity.

Other causes of NEP inter-annual variability are the radiation during the current vegetation season and the temperature at the end of the winter but the latter variable rather indicates an effect on the conifers interspersed in the plot. Overall, the photosynthetic capacity combined with these two factors explained about 75\% of NEP inter-annual variability.
\end{abstract}

\section{Introduction}

Terrestrial ecosystems play an important role in climate change mitigation as they reabsorb about one third of the carbon emitted by anthropogenic activity (Le Quéré et al., 2018). However, the captured quantity varies greatly from year to year and the mechanisms underlying this reabsorption remain poorly understood. It is thus difficult to predict how this component of the global carbon budget will evolve in the future. A better understanding of the mechanisms controlling the inter-annual variability of carbon sequestration by ecosystems is needed and long-term carbon exchange follow-ups could help to comprehend them. Since the end of the 1990s, several networks have been established around the world with this objective, e.g., Euroflux (Valentini et al., 2000); Asiaflux (Yamamoto et al., 2005); CarboEurope (Schulze et al., 2010); Ameriflux (Ameriflux, 2018); Ozflux (van Gorsel et al., 2018), Fluxnet (Baldocchi et al., 2001), ICOS (ICOS, 2018) and all of these used the eddy covariance method (Aubinet et al., 2012).

Measuring and analyzing long-term $\mathrm{CO}_{2}$ exchanges between ecosystems and the atmosphere with the eddy covariance method is challenging, not only because of the difficulties in performing measurements and maintaining apparatus over a long-term perspective, but also in view of the long-term evolution that both the ecosystem and the

\footnotetext{
* Corresponding author.

E-mail address: marc.aubinet@uliege.be (M. Aubinet).
} 
measurement system undergo during the experiment (Hurdebise et al., 2017). In addition, further difficulties occur at sites characterized by heterogeneous canopies, as is the case for many forested sites. These evolutions may blur the inter-annual variability signal and need careful data treatment to unravel real source/sink variability and artificial variations. One of the aims of this paper is to establish a data treatment that, as far as possible, disentangles the artificial from the natural causes of carbon sequestration inter-annual variability.

At present several long-term studies (over ten years) are available and allow analysis of inter-annual variation of Net Ecosystem Productivity (NEP) by ecosystems to be deepened. In particular, several studies focused on temperate deciduous forests (Saigusa et al., 2005; Urbanski et al., 2007; Granier et al., 2008; Pilegaard et al., 2011; Froelich et al., 2015; Wilkinson et al., 2012) and a synthesis for all ecosystem types has been proposed recently by Baldocchi et al. (2018). The causes of inter-annual NEP variability in forests have been found to be multiple and to vary according to the climate and forest type but also, for given climate and forest type, from site to site. Most often identified causes include the variability of meteorological conditions (spring temperature, intensity or length of drought season, radiation), of the biotic response to the environmental forcing (Richardson et al., 2007); long-term trends (Pilegaard et al., 2011) and natural or anthropic disturbances (logging, fires, thinning, insect infestations). However, it is recognized that, even for a given site, it is generally not possible to explain NEP inter-annual variability with a single factor (Pilegaard et al., 2011). Until recently, only a few studies (Granier et al., 2008; Zielis et al., 2014) considered the impact on NEP variability of lagged or carry-over effects. The importance of these effects is however more and more often recognized by ecologists who highlight impacts on wood increment (Rohner et al., 2016), masting (Vacchiano et al., 2017), net primary productivity (Campioli et al., 2011; Babst et al., 2014) or carbon dynamics (Starr et al., 2016). Carry-over effects of drought stress in the prior season on growth have also been highlighted by Bréda et al. (2006) and Granier et al. (2008) while Desai (2014) also reported that moisture stresses in the preceding season may inhibit photosynthesis.

The present study is based on twenty years of measurements performed at the Vielsalm station (VS) in the Ardennes, Belgium. The site is a mixed forest composed of deciduous and coniferous species and the set-up has been modified after twelve years of measurements, therefore a long-term analysis required a specific methodology that took site heterogeneity and data harmonization into account. This paper thus aims to answer two main questions:

- Is it possible to obtain robust long-term budgets and inter-annual variability estimates in a heterogeneous forest and, if yes, which methodology can be followed in order to avoid biases due to heterogeneity and set-up changes?

- What are the main causes of inter-annual variability at VS? This question will be addressed by specifically focusing on direct but also on carry-over effects of antecedent weather conditions on canopy photosynthetic capacity and NEP.

\section{Materials and methods}

\subsection{Site description}

The Vielsalm station is located in a mature mixed forest in the Ardennes region in eastern Belgium (50 $\left.18^{\prime} 18^{\prime \prime} \mathrm{N}, 5^{\circ} 59^{\prime} 53^{\prime \prime} \mathrm{E}\right)$ at an altitude of about $470 \mathrm{~m}$ a.s.l. The winds blow mainly from the South West (SW) and the North East (NE). The vegetation in the vicinity of the measurement tower is a mixture of coniferous species, mainly Douglas fir (Pseudotsuga menziesii [Mirb.] Franco), Norway spruce (Picea abies [L.] Karst.), silver fir (Abies alba Miller), western hemlock (Tsuga heterophylla [Raf.] Sarg.) and deciduous species, mainly European beech (Fagus sylvatica L.). The species distribution around the tower is heterogeneous, the SW sector being covered mainly by beech (28-29 $\mathrm{m}$ height) with some conifers interspersed (30-35 m height), while the other sectors are mostly covered by conifers. Douglas firs $(35-41 \mathrm{~m}$ height) are mainly concentrated in the NE sector. The Douglas firs were planted in 1935 and 1937 and the beeches in 1908. A more complete description of the vegetation has been given by Soubie et al. (2016). More complete descriptions of forest history have been given by Aubinet et al. (2001) for the period before 1996 and by Hurdebise et al. (2017) for the measurement period. Thinning was performed at the beginning of 2001, in mid-2003 and at the end of 2004. The soil at the site is $50-100 \mathrm{~cm}$ deep and is classified as a dystric cambisol. The soil surface is slightly sloping (3\%) in the NW direction. The climate is temperate maritime with an annual mean temperature around $8.4^{\circ} \mathrm{C}$ and an annual precipitation of $1000 \mathrm{~mm}$ without a dry season. The site provides a fetch of $1500 \mathrm{~m}$ in the SW direction and $500 \mathrm{~m}$ in the NE direction.

\subsection{Site instrumentation}

Eddy covariance measurements began at VS in August 1996 and are still running. Presently, VS is a candidate ICOS station. The present analysis focuses on the twenty years taken from 1 Jan 1997 to $31 \mathrm{Dec}$ 2016. The eddy covariance set-up (infrared gas analyzer LI-6262, LICOR Inc., Lincoln, NE, USA; 3D sonic anemometer SOLENT 1012R2, Gill Instruments, Lymington, UK) was installed at $36 \mathrm{~m}$ a.g.l. in August 1996 and moved to $40 \mathrm{~m}$ a.g.l. in March 1997. In May 2009, it was raised to $52 \mathrm{~m}$ a.g.l and, in 2014, it was updated in order to comply with ICOS recommendations (infrared gas analyzer LI-7200, LI-COR Inc., Lincoln, NE, USA; 3D sonic anemometer SOLENT HS50, Gill Instruments, Lymington, UK) and placed at $51 \mathrm{~m}$ a.g.l. The impact of measurement height on the flux estimates has been discussed in detail by Hurdebise et al. (2017).

Complementary measurements included above and within canopy air temperature and humidity, global, net and photosynthetically active radiation (PAR), soil temperature and moisture profiles, rainfall, mean atmospheric pressure, soil heat fluxes and $\mathrm{CO}_{2}$ concentration profiles below the measurement point. All these measurements are taken bihourly. Sensor type, number and position varied during the 20 year period. More complete descriptions of the meteorological set-up are given by Aubinet et al. (2001) for the original system and by Vincke et al. (2016) for the current system.

\subsection{Flux data treatment}

The Eddysoft software package (Kolle and Rebmann, 2007) was used to perform data acquisition and flux computation for all the years. Computation and correction followed the recommended standard procedures (Rebmann et al., 2012). The double rotation method was used for coordinate rotation. The first steps of classical quality control were applied to the raw data (spike detection and stationarity test) and only those data meeting the quality criteria were retained (Aubinet et al., 2000). The spectral correction was based on the comparison between $\mathrm{CO}_{2}$ and sensible heat cospectra (Foken et al., 2012), following a procedure described by De Ligne (2016): transfer functions and their cut off frequencies were obtained as the ratio of $\mathrm{CO}_{2}$ and sensible heat cospectra, computed on each high quality half hour (stationarity criterion met; sensible heat $>20 \mathrm{Wm}^{-2}$ ). These functions were combined with a reference non attenuated local cospectrum (sensible heat cospectrum) in order to determine the correction factors. Look up tables grouping correction factors by wind velocity classes were built for 8 different periods (between each apparatus change), two wind sectors and two stability classes (stability threshold: $\mathrm{z} / \mathrm{L}=0.003$ ).

Finally, data that did not meet the stationarity criteria (threshold $30 \%$ ) were removed (Foken and Wichura, 1996). After these operations, $82 \%$ of the total data was available for analysis (Table SM I). 


\subsubsection{Data selection}

As in many forested sites, the surrounding forest is heterogeneous. This implies that, before an analysis of flux inter-annual variability can be performed, it is necessary to disentangle the real variability of source and sink intensities from artefacts due to heterogeneity. This is especially critical at VS where the two most frequent wind directions (SW and NE) correspond not only to contrasting weather conditions but also to contrasting vegetation stands (Aubinet et al., 2005). As is usual in Western Europe, SW winds are associated with a weather disturbance regime corresponding generally to mild temperatures and a larger occurrence of cloudy and rainy periods and NE winds with an anticyclonic regime corresponding to periods with more sunny and dry days, with higher temperatures in summer and lower temperatures in winter (e.g., Malardel, 2005). In addition, at VS, the NE sector is covered by conifers and dominated by Douglas fir, while the SW sector is covered mainly by beech with some sparse conifers. We decided to focus on the SW sector $\left(180^{\circ} 330^{\circ}\right)$ for two reasons: first, anticyclonic conditions prevailed only $20 \%$ of the time and the NE data amounts were not sufficient to allow an inter-annual variability study to be performed. Secondly, as the Douglas firs were taller, the proximity of the measurement point to the canopy could induce biases (Hurdebise et al., 2017). As a result, $34 \%$ of data points were further removed from the initial set. However, this removal was biased because it mainly concerned fluxes measured during anticyclonic conditions. The data gap filling had thus to take this "meteorological bias" into account, as discussed in Section 2.3.3.

\subsubsection{Low turbulence filtering}

After adding a storage term to the selected turbulent $\mathrm{CO}_{2}$ fluxes, the resulting half-hourly fluxes $\left(\mathrm{NEP}_{h}\right)$ were filtered in order to remove those collected during periods of low turbulence ( $u_{*}$ filtering; $u_{*}$ threshold: $0.4 \mathrm{~m} \mathrm{~s}^{-1}$ ). The computation of the storage term was based on half hourly profile measurements, following the procedure described by Aubinet et al. (2001). In order to avoid additional gaps due to the absence of profile measurements at certain times, a specific look-up table was generated to fill gaps in the storage flux data. To this end, available storage measurements for the 20 year period were sorted by period of the year (resolution: 1 month), hour of the day (resolution: one half hour) and $u_{*}$ intensity (resolution: $0.1 \mathrm{~m} \mathrm{~s}^{-1}$ ) into one look-up table that was then used to fill the gaps. This approach was preferred to a regression between storage estimates with a complete profile and with only the top $\mathrm{CO}_{2}$ concentration measurements, as those regressions have been generally found poor at sites where decoupling is important (Nicolini et al., 2018). This procedure concerned $8 \%$ of the data in the studied wind sector (Table SM I) but, more importantly, it avoided a long-term data gap in 2009 and 2010 when the concentration profile was missing following a structural change to the tower (Table SM II). Finally, after these different operations, $31 \%$ (37\% of day data; $24 \%$ of night data) of the data remained available (Table SM I). Thanks to the use of storage gap filling, this percentage was more or less the same for each year (Table SM II), corresponding to an amount of 4000-6000 available half hours each year.

\subsubsection{Data gap filling and sum computation}

In view of the large number of data gaps due to the wind direction screening and of the meteorological bias described above, a special attention should be brought to the data gap filling. We thus preferred to set-up our own approaches, better suited to the site specificities, rather than using turnkey programs (i.e. Reichstein et al., 2005). The $\mathrm{NEP}_{\mathrm{h}}$ data gaps were filled using two different procedures, combining look-up tables and mean diurnal variations. A flow chart of the procedures is given in Fig. 1.

Six look-up tables (LUT, Fig. 1) were constituted, grouping selected data by ten-day periods, by temperature class ( $2 \mathrm{~K}$ resolution) for night fluxes (PPFD $<5 \mu \mathrm{mol} \mathrm{m} \mathrm{m}^{-2} \mathrm{~s}^{-1}$ ) and by PPFD class $\left(100 \mu \mathrm{mol} \mathrm{m}^{-2} \mathrm{~s}^{-1}\right.$ resolution) for day fluxes. In one day and one night look-up table $\left(\mathrm{LUT}_{\mathrm{d}, \mathrm{y}}\right.$ and $\left.\mathrm{LUT}_{\mathrm{n}, \mathrm{y}}\right)$, the average $\mathrm{NEP}_{\mathrm{h}}$ were computed separately for each year; in the others, they were averaged over longer periods. In order to take the 2009 measurement height change into account, two different periods were used: 1997-2008 and 2009-2016.

Mean diurnal variation (MDV) was also operated by building MDV tables that are similar to look-up tables but rely on different selection criteria. Here data selection and gathering was operated by ten-day periods and half-hour of the day. Three MDV tables were constituted, one computing $\mathrm{NEP}_{\mathrm{h}}$ every year $\left(\mathrm{MDV}_{\mathrm{y}}\right)$ and the others averaging $\mathrm{NEP}_{\mathrm{h}}$ over the 1997-2008 and the 2009-2016 periods.

The advantage of using look-up tables based on PPFD and temperature classes is that they allow a correction of the meteorological bias (Section 2.3.1) to be made. Even if periods of high radiation and extreme temperatures are less frequent under the weather disturbance regime, they are sufficiently numerous to constitute specific classes and allow realistic gap filling. This was not the case with mean diurnal variation which depicts only average fluxes under the weather disturbance regime. Besides this, the advantage of using yearly values rather than long-term averages is that the former better takes inter-annual variability into account. The data gap filling procedure should thus preferentially use yearly look-up tables (Fig. 1). This was made, which allowed about $80 \%$ of the gaps to be filled. However, for the remaining gaps, a choice between yearly mean diurnal variation and long-term averaged look-up tables must be operated. Two procedures were then followed. Procedure 1 used yearly mean diurnal variations in order to better reflect the amplitude of inter-annual variability and it was used to compute yearly anomalies. Procedure 2 used averaged look up tables and was applied to provide the long-term carbon budgets as it better took the meteorological bias into account. Finally the last remaining gaps were filled with long-term averaged mean diurnal variation.

Although the difference between procedures affects only $11 \%$ of the total data, their impact on the mean annual sequestration is substantial, amounting to about $34 \mathrm{~g} \mathrm{C} \mathrm{m}^{-2} \mathrm{yr}^{-1}$ (Fig. 2a). An approach based on MDV only (not shown) would have differed from our $\mathrm{NEP}_{\mathrm{y}}$ estimates by $75 \mathrm{~g} \mathrm{C} \mathrm{m}^{-2} \mathrm{yr}^{-1}$, which is much larger than the differences between gap filling methods predicted by Moffat et al. (2007). This is probably because of the larger size of the data gaps. However, as the MDV approach has been clearly identified as skewed due to meteorological bias, we did not consider this difference as an uncertainty source.

Besides this, procedure 1 better took inter-annual variability into account as $93 \%$ of the data were measured or estimated on the basis of data of the current year, while in procedure 2 this percentage was limited to $80 \%$.

The impact of the storage correction was especially important on years during which storage measurements were not available (mainly 2009 and 2010). For these years the classical procedure would had automatically skipped some data, while turbulent measurements were of good quality and this could be avoided by applying the storage data gap procedure.

Daily $\left(\mathrm{NEP}_{\mathrm{d}}\right)$ and yearly $\left(\mathrm{NEP}_{\mathrm{y}}\right)$ net ecosystem productivities were finally obtained by $\mathrm{NEP}_{\mathrm{h}}$ summation.

\subsection{Derived variables for inter-annual variability computation}

\subsubsection{Anomaly computation}

The anomalies were computed on a daily basis as the difference between the daily NEP $\left(\mathrm{NEP}_{\mathrm{d}}\right)$ of the considered day and those of the same DOY averaged over an extended period. Two averaging periods, before and after the tower change (in April-May 2009), were considered in order to remove the impact of measurement height change on inter-annual variability. All anomaly computations were based on procedure 1 because it better captures inter-annual variability. Anomalies at a larger time scale (year, period) were computed by summation of the daily anomalies. 


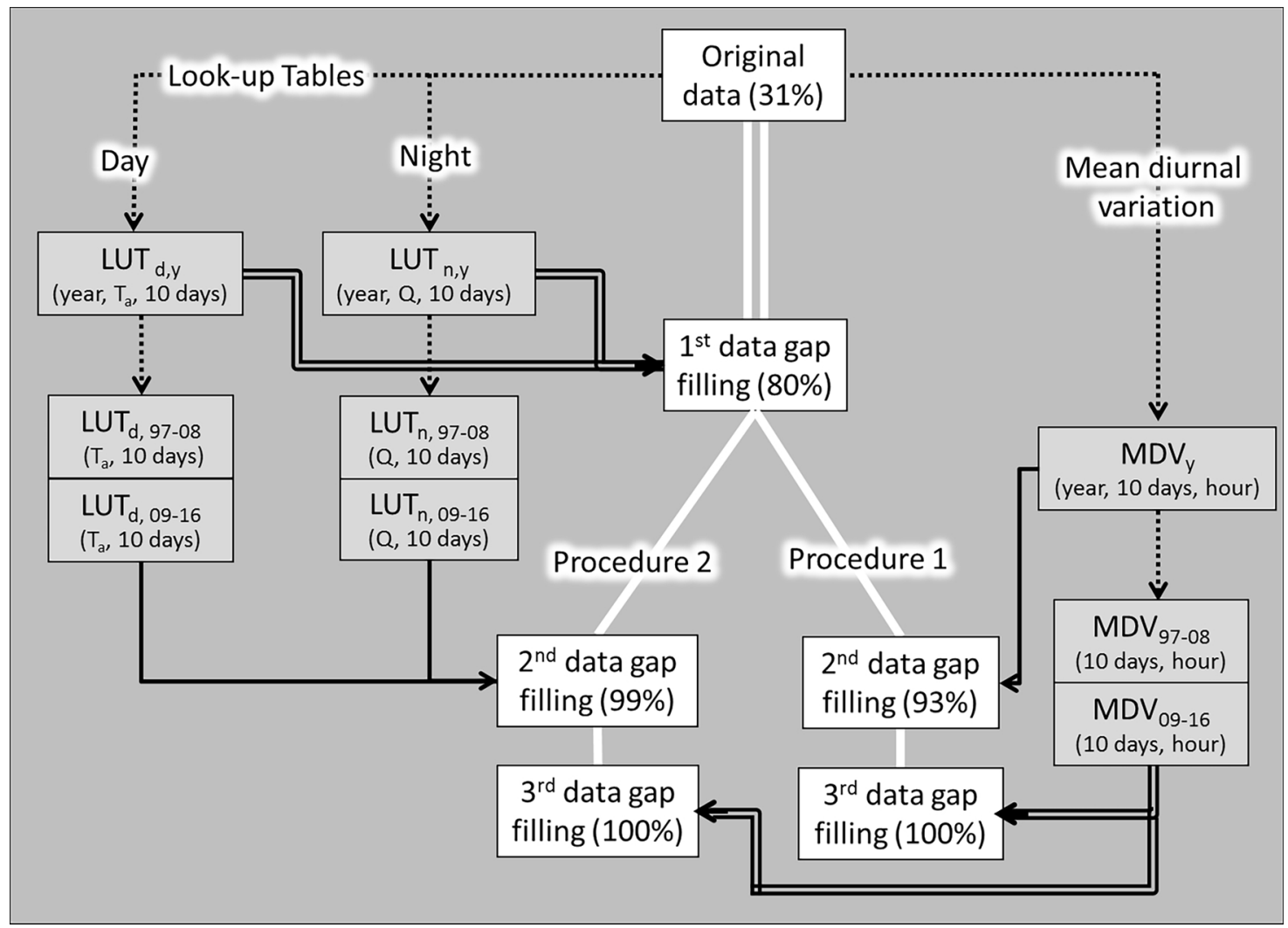

Fig. 1. Organigram of the data gap filling procedure. LUT: Look Up table; MDV : Mean diurnal variation.

\subsubsection{Physiologic variables}

In order to derive the characteristics of the canopy exchange capacity, independently of PAR, $\mathrm{NEP}_{\mathrm{h}}$ to PAR $(Q)$ responses were derived from direct measurements for every decade. We used an exponential curve (Mitscherlich equation, Aubinet et al., 2001) and derived assimilation at PAR saturation $\left(A_{\max }\right)$, quantum efficiency $(\alpha)$, dark respiration $\left(R_{\mathrm{d}}\right)$ and assimilation at $700 \mu \mathrm{mol} \mathrm{m}^{-2} \mathrm{~s}^{-1}\left(A_{700}\right)$, according to Eqs. (1) and (2). The last parameter was preferred to $A_{\max }$ and $\alpha$ as an estimate of canopy photosynthetic capacity.

$N E P_{h}=A_{\max }\left[1-\exp \left\{\frac{-\alpha Q}{A_{\max }}\right\}\right]-R_{d}$

$A_{700}=A_{\max }\left[1-\exp \left\{\frac{-\alpha 700}{A_{\max }}\right\}\right]$

Anomalies of these parameters $(A A)$ were computed similarly to those for NEP.

\subsubsection{Uncertainty estimates}

Uncertainties result from random errors or from an imperfect correction of systematic errors (JCGM, 2008). In eddy covariance, random errors include errors due to the stochastic nature of turbulence, to the instrument system and to changes in footprint while systematic errors result from unmet assumptions and methodological challenges, from instrumental calibration and design or from data processing (Richardson et al., 2012; Mauder et al., 2013).

To quantify the uncertainty on $\mathrm{NEP}_{\mathrm{y}}$ at VS, we considered four sources: the total random error, including the three causes mentioned above, and three systematic errors. We focused on the night flux underestimation (unmet assumptions), the frequency correction (instrumentation design) and the gap filling (data processing). Calibration errors, instrumental errors or density effects were not taken into account, deeming that enough precautions had been taken to limit them.
In each case the uncertainty was not defined as the error itself but as resulting after the correction of the systematic error, due to an imperfect correction. Their estimation and the way they propagate in budgets were described below. Results are given in Table 1.

Uncertainties due to the total random error and to gap filling were both estimated at a half hourly scale. The first one was estimated for each measurement using the relation based on the daily difference approach proposed by Richardson et al. (2006) for forests. The second was estimated for each gap filled data as 1.96 times the flux standard deviation in the LUT or the MDV class used to fill the gap. They were summed quadratically together to get annual sums (Table 1 , column C4).

We considered that the uncertainty associated to the night flux error resulted from an inadequate $u_{*}$ threshold choice. It was estimated at an annual scale: $\mathrm{NEP}_{\mathrm{y}}$ was computed several times, using each time a different (but constant) $u_{*}$ threshold chosen in the range where normalized fluxes appear independent of $u_{*}$ (namely, between 0.35 and $0.45 \mathrm{~ms}^{-1}$ at VS). For each year, a $\mathrm{NEP}_{\mathrm{y}}$ distribution was thus obtained and the uncertainty was estimated as 1.96 times its standard deviation (Table 1, column C6).

The main source of uncertainty remaining after frequency correction is in the correction factor determination (Section 2.3). As the set up changes were operated at a frequency lower than once per year, it was considered as systematic at a yearly scale and computed for each year as the product of the flux and 1.96 times the average standard error of the correction factor (Table 1, column C8).

A global yearly uncertainty was obtained by summing quadratically the three preceding estimates. Global yearly uncertainties were averaged quadratically from 1997 to 2008 and from 2009 to 2016 (before and after the measurement height change) in order to obtain global multi-year uncertainties (Table 1, columns M4, M6 and M8). Finally, uncertainties on annual budget anomalies were obtained by summing quadratically global yearly and global multi-year uncertainties (Table 1, column C9). 


\subsubsection{Growth index computation}

Twenty-four dominant beeches were cored at the end of 2011 at breast height with an increment borer (two perpendicular cores per tree). The individual ring widths from 1972 to 2011 were measured using the image analysis software WinDENDRO (Regent Instruments Canada Inc. (Guay et al., 1992)) and were then cross-dated by detecting regional pointer years, which were defined as those calendar years for which at least $75 \%$ of the cross dated trees presented a radial growth variation higher than 10\% (Becker et al., 1994).

Tree ring indexes were computed by Soubie (2014) using a procedure proposed by Lebourgeois and Mérian (2012): low and intermediate frequencies were removed by dividing each individual series by a polynomial function adjusted on the forty year long series and by averaging these ratios by year. By this, a stationary time series with a mean of 1 and a homogeneous variance was obtained for each tree. The tree ring index was then computed by averaging these values on the 24 trees. Their uncertainty was estimated as 1.96 times the standard error of the mean. All computations were made using the R-software and the “dplR" package (Bunn, 2010; Mérian, 2013).

\section{Results}

\subsection{Budget and inter-annual variability}

Time series of NEP and principal weather variables are presented in the Supplementary Material, Fig. SM1. The average sequestration over twenty years (computed with procedure 2) was $411 \mathrm{~g} \mathrm{C} \mathrm{m}^{-2} \mathrm{yr}^{-1}$ (Table 1, Fig. 2a) but this differed strongly $\left(107 \mathrm{~g} \mathrm{C} \mathrm{m}^{-2} \mathrm{yr}^{-1}\right)$ between the periods before and after measurement height change in 2009. This difference is much larger than the uncertainties associated with the eddy covariance method, which reached 7 and $11 \mathrm{~g} \mathrm{C} \mathrm{m}^{-2} \mathrm{yr}^{-1}$ on the 1997-2009 and 2009-2016 long-term budgets respectively (Table 1, column C9). The impact of measurement height change on fluxes has been discussed by Hurdebise et al. (2017). They showed that, in some sectors, the system was in the roughness sublayer, which could affect similarity conditions. However, they also showed that it was not the case in the SW sector studied here, so that the difference in the present case is more likely to be due to footprint changes.

However, as these errors are mainly systematic, they are expected to less affect year to year changes. For this reason, the following analysis will be mainly based on the anomalies computed, as described in Section 2.4.1. No further standardization is operated as the $\mathrm{NEP}_{\mathrm{y}}$ standard deviation was hardly affected by the measurement height change (91 and $95 \mathrm{~g} \mathrm{C} \mathrm{m}^{-2} \mathrm{yr}^{-1}$ for 1997-2009 and 2009-2016 respectively). The uncertainties for anomalies, mainly associated with the eddy covariance method, are of the order of $30 \mathrm{~g} \mathrm{C} \mathrm{m}^{-2} \mathrm{yr}^{-1}$ (Table 1).

For six years, the $\mathrm{NEP}_{\mathrm{y}}$ anomaly $\left(\mathrm{NEPA}_{\mathrm{y}}\right)$ was comprised in the classes $[-30 ; 30] \mathrm{m}^{-2} \mathrm{yr}^{-2} \mathrm{yr}^{-1}$, i.e., lower than their own uncertainty (1998, 2001, 2002, 2007, 2010 and 2013, Fig. 2b). Seven years (1999, 2003, 2006, 2008, 2009, 2014 and 2015) were characterized by a positive anomaly (larger than average sequestration) and seven years (1997, 2000, 2004, 2005, 2011, 2012 and 2016) by a negative anomaly (lower than average sequestration). Among these, 2000 appeared exceptional, the $\mathrm{NEPA}_{\mathrm{y}}$ reaching $-200 \mathrm{~g} \mathrm{C} \mathrm{m}^{-2} \mathrm{yr}^{-1}$, more than twice the standard deviation. This year was found to be marked by a bark beetle attack that weakened and even killed some trees (La Spina et al., 2013) as discussed below.

\subsection{Anomaly analysis}

At a yearly scale, no significant correlation appeared between $\mathrm{NEPA}_{\mathrm{y}}$ and yearly averaged physiologic and weather variables (Table 2).

The following strategy was then followed: the year was divided in four periods corresponding to given vegetation development stages and we focused on the three periods that had the larger impact on yearly NEP $\left(\mathrm{NEP}_{\mathrm{y}}\right)$. On these periods, direct correlations between periodical NEPA and weather (temperature, PAR, VPD, precipitation) or

Table 1

Yearly carbon sequestration and anomalies computed with the two procedures $\left(\mathrm{g} \mathrm{C} \mathrm{m}^{-2} \mathrm{yr}^{-1}\right)$ and uncertainties. For details see text.

\begin{tabular}{|c|c|c|c|c|c|c|c|c|}
\hline \multirow{2}{*}{$\begin{array}{l}\text { Year } \\
\text { C1 }\end{array}$} & \multirow{2}{*}{$\begin{array}{l}\mathrm{NEP}_{\mathrm{y}} \\
\text { (Procedure 2) } \\
\mathrm{C} 2\end{array}$} & \multirow{2}{*}{$\begin{array}{l}\mathrm{NEPA}_{\mathrm{y}} \\
\text { (Procedure 1) } \\
\text { C3 }\end{array}$} & \multirow{2}{*}{$\begin{array}{l}\text { Random and } \\
\text { Data gap filling } \\
\text { uncertainty } \\
\text { C4 }\end{array}$} & \multicolumn{2}{|c|}{$\begin{array}{l}\mathrm{u}^{*} \text { correction } \\
\text { uncertainty }\end{array}$} & \multicolumn{2}{|c|}{$\begin{array}{l}\text { Frequency correction } \\
\text { uncertainty }\end{array}$} & \multirow{2}{*}{$\begin{array}{l}\text { Total } \\
\text { Uncertainty } \\
\text { on anomalies } \\
\text { C9 }=\left(\mathrm{C} 4^{2}+\mathrm{C}^{2}+\mathrm{C}^{2}+\mathrm{M} 4^{2}+\mathrm{M}^{2}+\mathrm{M} 8^{2}\right)^{0.5}\end{array}$} \\
\hline & & & & $\begin{array}{l}\text { Systematic } \\
\text { (corrected) } \\
\text { C5 }\end{array}$ & $\begin{array}{l}\text { Remaining } \\
\text { C6 }\end{array}$ & $\begin{array}{l}\text { Systematic } \\
\text { (corrected) } \\
\text { C7 }\end{array}$ & $\begin{array}{l}\text { Remaining } \\
\text { C8 }\end{array}$ & \\
\hline 1997 & & -56 & 17 & 140 & 21 & 30 & 4 & 28 \\
\hline 1998 & & 8 & 17 & 50 & 23 & 37 & 5 & 30 \\
\hline 1999 & & 99 & 17 & 79 & 26 & 43 & 2 & 32 \\
\hline 2000 & & -200 & 16 & 97 & 13 & 19 & 1 & 22 \\
\hline 2001 & & 18 & 16 & 51 & 15 & 36 & 1 & 22 \\
\hline 2002 & & 8 & 16 & 105 & 8 & 35 & 1 & 19 \\
\hline 2003 & & 83 & 16 & 107 & 17 & 41 & 2 & 24 \\
\hline 2004 & & -55 & 16 & 95 & 13 & 32 & 1 & 22 \\
\hline 2005 & & -87 & 16 & 87 & 10 & 27 & 1 & 20 \\
\hline 2006 & & 48 & 17 & 55 & 16 & 40 & 2 & 24 \\
\hline 2007 & & 10 & 16 & 64 & 14 & 36 & 3 & 22 \\
\hline 2008 & & 123 & 16 & 84 & 14 & 45 & 3 & 23 \\
\hline 2009 & & 148 & 22 & 133 & 14 & 34 & 3 & 28 \\
\hline 2010 & & -10 & 21 & 133 & 12 & 21 & 4 & 27 \\
\hline 2011 & & -115 & 20 & 178 & 22 & 11 & 2 & 31 \\
\hline 2012 & & -68 & 20 & 188 & 17 & 16 & 3 & 29 \\
\hline 2013 & & -8 & 21 & 134 & 26 & 21 & 4 & 36 \\
\hline 2014 & & 48 & 21 & 168 & 36 & 25 & 0 & 43 \\
\hline 2015 & & 92 & 20 & 139 & 17 & 29 & 0 & 28 \\
\hline 2016 & & -86 & 20 & 269 & 28 & 15 & 0 & 36 \\
\hline Averages & & & M4 & & M6 & & M8 & on budget \\
\hline 1997-2009 & -454 & & 5 & & 5 & & 1 & 7 \\
\hline 2009-2016 & -347 & & 7 & & 8 & & 1 & 11 \\
\hline 20 Years & -411 & & & & & & & \\
\hline
\end{tabular}



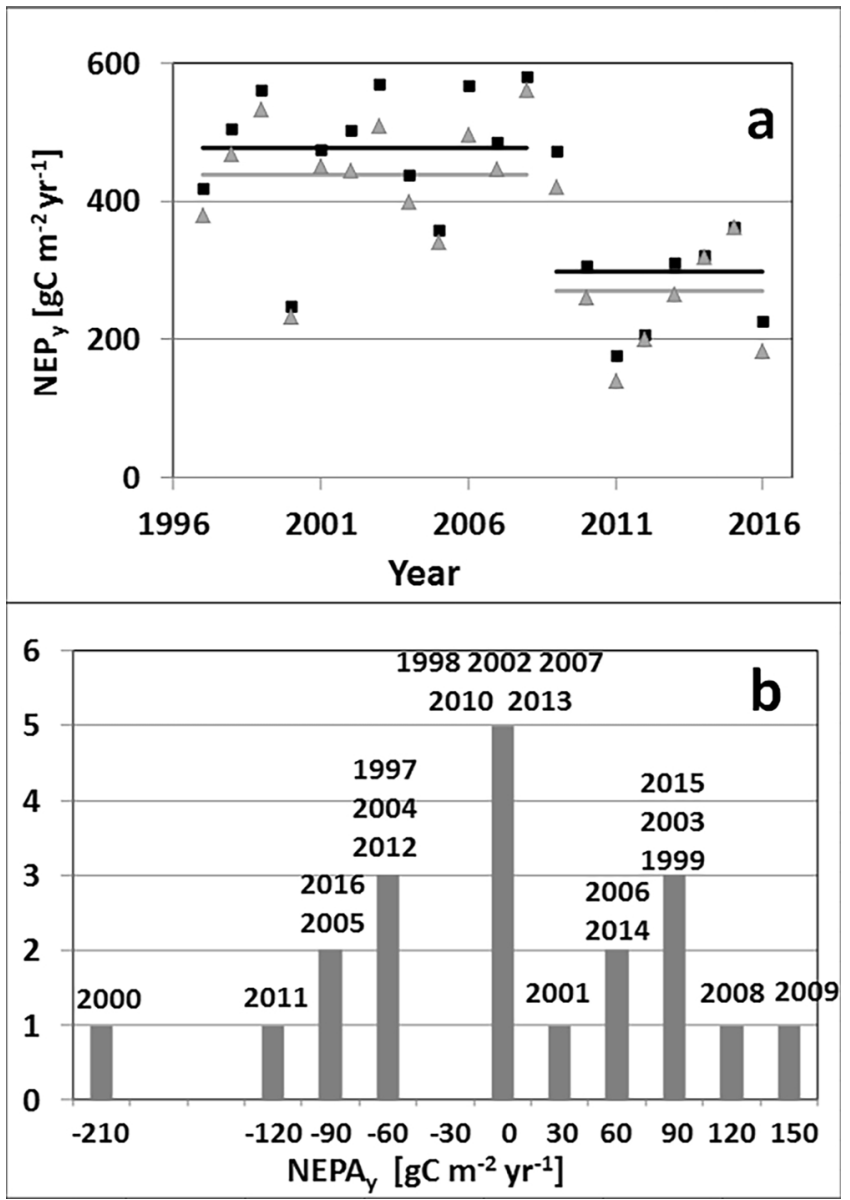

Fig. 2. a: Yearly NEP estimated using different data gap filling procedures: Black squares: Procedure 1, grey triangles: Procedure 2. For details, see Section 2.3.3. b: frequency distribution of $\mathrm{NEPA}_{\mathrm{y}}$.

Table 2

Correlation coefficients between $\mathrm{NEPA}_{\mathrm{y}}$ and corresponding physiological and climatic variables at different time scales. Significant correlations $(\mathrm{p}<0.05)$ are indicated in bold.

\begin{tabular}{lcccc}
\hline & Year & Spring & Veg. S. & Fall \\
\hline $\mathrm{T}_{\mathrm{a}}$ & 0.02 & $\mathbf{0 . 5 4}$ & 0.37 & 0.26 \\
$\mathrm{~V}$ & 0.22 & $\mathbf{0 . 5 0}$ & 0.18 & 0.17 \\
$\mathrm{Q}$ & 0.20 & $\mathbf{0 . 5 3}$ & 0.32 & 0.27 \\
$\mathrm{P}$ & 0.01 & -0.14 & -0.12 & -0.26 \\
$\mathrm{AA}$ & 0.32 & 0.37 & $\mathbf{0 . 6 4}$ & 0.22 \\
$\mathrm{R}_{\mathrm{d}}$ & 0.39 & 0.01 & -0.08 & 0.30 \\
\hline
\end{tabular}

physiological (photosynthetic capacity, dark respiration) variable anomalies on the same period were sought, using stepwise regression. Carry-over effects of weather conditions on NEPA or $A_{700}$ anomalies (AA) were then sought by computing lagged correlation between these variables and weather variable anomalies. Finally, direct and lagged correlations were combined in order to find the best predictors of inter annual $\mathrm{NEP}_{\mathrm{y}}$ variability.

\subsubsection{Direct correlations}

The three periods of the year that were considered were: Spring (DOY 30-150), before full leaf development is reached by the beech, Vegetation season (DOY 150-250), corresponding to full leaf development and Fall (DOY 250-330), corresponding to the leaf senescence period. The vegetation season was the period during which both NEP and NEPA were the most intense: $\mathrm{NEP}_{\mathrm{vs}}$ reached $84 \%$ of $\mathrm{NEP}_{\mathrm{y}}$ in
1997-2008 and $119 \%$ of $\mathrm{NEP}_{\mathrm{y}}$ in $2009-2016$ while $\mathrm{NEP}_{\mathrm{vs}}$ variability explained $74 \%$ of $\mathrm{NEP}_{\mathrm{y}}$ variability (Fig. 3a). Spring NEP (NEP $\mathrm{Np}_{\mathrm{sp}}$ ) contributed from $23 \%$ (1997-2008) to 30\% (2009-2016) of annual NEP $\left(\mathrm{NEP}_{\mathrm{y}}\right.$ ). The correlation between $\mathrm{NEPA}_{\mathrm{sp}}$ and $\mathrm{NEPA}_{\mathrm{y}}$ was poor (Fig. $3 \mathrm{~b}$ ) but appeared much more important after the relation with $\mathrm{NEPA}_{\mathrm{vs}}$ had been removed (Fig. 3c). Finally, fall NEP $\left(\mathrm{NEP}_{\mathrm{f}}\right)$ constituted a minor part of the yearly budget $\left(5 \%\right.$ of $\mathrm{NEP}_{\mathrm{y}}$ in $1997-2008 ;-15 \%$ of $\mathrm{NEP}_{\mathrm{y}}$ in 2009-2016) and their anomalies were not correlated with $\mathrm{NEPA}_{\mathrm{y}}$ (Fig. 3d-e).

Some direct correlations with physiologic and weather variables appeared (Table 2): NEPA was correlated with photosynthetic capacity anomalies (AA) in the vegetation season, while correlations with weather variables anomalies (air temperature, PAR, VPD) appeared only in spring. No significant correlation was found for $\mathrm{NEPA}_{\mathrm{f}}$.

As some correlations could be hidden by others, stepwise regressions were developed in order to investigate direct correlations more deeply. Stepwise regression steps between $\mathrm{NEPA}_{\mathrm{vs}}$ and main driving variables were presented (Table 3, Fig. 4a-c). As expected from Table 2, a significant correlation with the photosynthetic capacity (AA vs, ) appears at step 1 (Fig. 4a). At step 2, significant correlations were obtained between the residuals of this relation and $Q$ and $T_{\mathrm{a}}$ anomalies. The former was retained as the most significant (Fig. 4b). At step 3, no significant relations remained and the correlation with $T_{\mathrm{a}}$ anomaly disappeared. The two- variable regression was thus the best and explained about $58 \%$ of the $\mathrm{NEPA}_{\mathrm{vs}}$ (Fig. 4c).

An almost similar pattern was found for $\mathrm{NEPA}_{\mathrm{sp}}$ (Fig. 4d-f) with the difference that the correlation with $Q$ anomaly was larger than those with AA at the first step. At the end the main direct driving variables were the same for the two periods and explain about $50 \%$ of the variability.

\subsubsection{Lagged correlations}

For each of the three periods, significant lagged correlations appeared between NEPA and some weather variable anomalies characterizing preceding year's vegetation season (between DOY 150 and 250 (y-1), Fig. 5a-c, dashed ellipses). These correlations were more or less important according to the variable and the season considered; they were not all significant but obey to a similar pattern: correlations with PAR, air temperature and VPD anomalies were negative and those with precipitation anomalies were positive and at least one of these variables had a significant correlation with NEPA.

A correlation of $\mathrm{NEPA}_{\mathrm{sp}}$ with the previous winter temperature anomaly (around DOY 1) is also clearly apparent, in addition to the direct correlation with all weather variables (DOY 50 and beyond), as discussed in Section 3.2 (Fig. 5a, dotted ellipse).

Finally, significant positive correlations between $\mathrm{NEPA}_{\mathrm{sp}}$ and temperature anomaly around DOY 155 of the preceding year (Fig. 5a) and between $\mathrm{NEPA}_{\mathrm{f}}$ and weather conditions of the current year's vegetation season (DOY 160-200, Fig. 5c) also appear.

Carry-over effects of preceding year weather conditions on NEPA operated through mechanisms which, supposedly, involve tree physiology. Considering that AA could be a tracer for these mechanisms, we also analyzed lagged correlations between weather variables and this variable (Fig. 5d-f). For this analysis, years 1997 and 2000 were excluded, the first due to the absence of meteorological data before August 1996, the second because the strong AA observed for this year was clearly due to another cause (the bark beetle attack) that was independent of the weather conditions discussed here.

Although the correlations were less important, a similar coherent scheme appeared: lagged correlations with weather variable anomalies during the preceding vegetation season (DOY $150(\mathrm{y}-1)$ ) were significant for $\mathrm{AA}_{\mathrm{vs}}$ and $\mathrm{AA}_{\mathrm{f}}$ (Fig. 5e and $\mathrm{f}$, dashed ellipses) but not for $\mathrm{AA}_{\mathrm{sp}}$ (Fig. 5d). The two first correlations confirm that carry-over effects could affect photosynthetic capacity. The absence of correlation in spring is not surprising: first this period covers the leaf initiation and growth and thus also depends on leaf unfolding dynamics; secondly, AA 


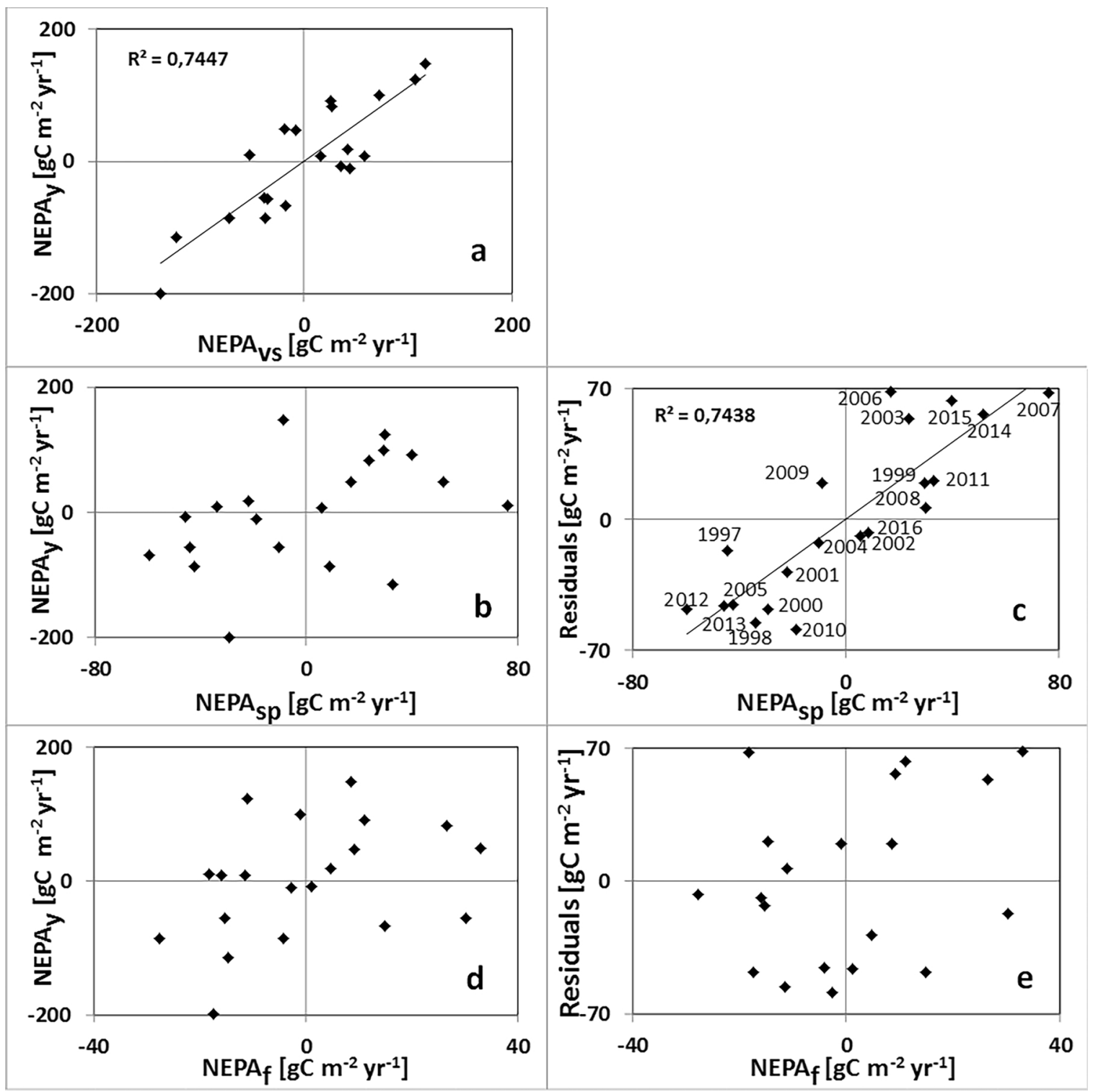

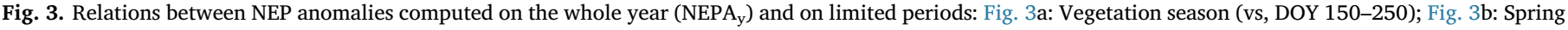

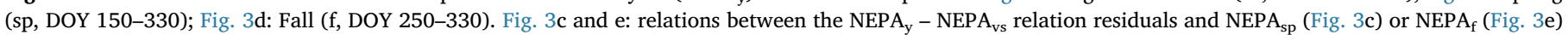
anomalies.

estimates during this period are strongly influenced by the conifers present in the sub-plot. Both contribute to blur a signal that could result from carry-over effects. Besides this, the positive correlation with winter temperature anomaly (around DOY 1) observed for $\mathrm{NEP}_{\mathrm{sp}}$ (Fig. 5d, dotted ellipse) could attest the impact of temperature on assimilation starting dates in the stand.

Finally a positive correlation between $\mathrm{AA}_{\mathrm{vs}}$ and precipitation (main peak in DOY 60-70, Fig. 5e, dotted ellipses) also appears.

A stepwise regression was also developed in order to quantify the impact of lagged effects on $\mathrm{AA}_{\mathrm{vs}}$ and $\mathrm{AA}_{\mathrm{f}}$. However, it was limited to the first step as no significant relation remained at the second step. The best correlations at step 1 were obtained for both variables with previous vegetation season saturation deficit $(\mathrm{p}=0.016$ and 0.034 for vegetation season and fall, respectively) (Fig. $6 \mathrm{a}$ and c). In addition, $\mathrm{AA}_{\mathrm{vs}}$ correlation with spring precipitation anomalies was presented on (Fig. 6b).

\subsubsection{Synthesis: main sequestration inter-annual variability drivers}

In order to synthesize the impact of direct and carry-over effects on $\mathrm{NEP}_{\mathrm{y}}$ inter-annual variability, a stepwise regression of $\mathrm{NEPA}_{\mathrm{y}}$ with all direct and lagged driving variables of seasonal NEPA was developed in order to find the best predictors of $\mathrm{NEP}_{\mathrm{y}}$ inter-annual variability. Step 1 and 2 showed that the most important driving variables were the photosynthetic capacity and the PAR during vegetation season as already suggested by the impact of these variables on $\mathrm{NEPA}_{\mathrm{vs}}$ (Fig. 4a, b). At step 3 (Fig. 7a), three variables were tested: $\mathrm{T}_{0-60}, V_{\mathrm{y}-1}$ and $V_{60-90}$. The best correlation improvement was obtained by adding early year temperature $\left(\mathrm{T}_{0-60}, \mathrm{Fig} .5 \mathrm{~d}\right)$. Inclusion of carry-over effects through the introduction of $V_{\mathrm{y}-1}$ did not improve the correlation so well, probably because its effect was already taken into account, through the $A_{700 v s}$ parameter. Finally, the correlation improvement brought at step 4 by introducing $V_{60-90}$ as a fourth variable was very small. The three-variable regression $\left(A A_{\mathrm{vs}}, Q_{\mathrm{vs}}\right.$ and $\mathrm{T}_{0-60}$ ) explained about $75 \%$ of the interannual variability and the difference between simulated and observed anomalies was lower than anomaly uncertainty $\left(30 \mathrm{~g} \mathrm{C} \mathrm{m}^{-2} \mathrm{yr}^{-1}\right)$ for 15 years (Fig. 7).

Finally, a significant relation was found between $\mathrm{NEPA}_{\mathrm{y}}$ and tree ring index based on beech wood increment (Fig. 8). 
Table 3

Stepwise regression: correlations between vegetation season and spring NEP anomalies and selected climate and physiological variables at each step of the regression. Significant correlations $(\mathrm{p}<0.05)$ are indicated in bold. Table 3a: Vegetation season; Table 3b: Spring.

\begin{tabular}{|c|c|c|c|c|c|c|}
\hline $\mathrm{a}$ & $\operatorname{Pr}$ & $T_{\mathrm{a}}$ & $R_{\mathrm{d}}$ & $Q$ & $A A$ & $\begin{array}{l}\text { Model } \\
\text { quality }\end{array}$ \\
\hline \multicolumn{7}{|c|}{$\mathrm{NEPA}_{\mathrm{vs}}$} \\
\hline Rsq & n.s. & 0.22 & n.s. & n.s. & 0.44 & 0.44 \\
\hline $\mathrm{p}$ & & 0.04 & & & 0.002 & 0.002 \\
\hline \multicolumn{7}{|c|}{ Residuals Step 1} \\
\hline Rsq & n.s. & 0.26 & n.s. & 0.33 & & 0.64 \\
\hline $\mathrm{p}$ & & 0.02 & & 0.01 & & 0.001 \\
\hline \multicolumn{7}{|c|}{ Residuals Step 2} \\
\hline Rsq & n.s. & n.s. & n.s. & & & \\
\hline \multicolumn{7}{|l|}{$\mathrm{p}$} \\
\hline $\mathrm{b}$ & $\operatorname{Pr}$ & $T_{\mathrm{a}}$ & $R_{\mathrm{d}}$ & $A_{700}$ & $Q$ & $\begin{array}{l}\text { Model } \\
\text { quality }\end{array}$ \\
\hline \multicolumn{7}{|c|}{$\mathrm{NEPA}_{\mathrm{sp}}$} \\
\hline Rsq & n.s. & 0.29 & n.s. & 0.29 & 0.36 & 0.36 \\
\hline $\mathrm{p}$ & & 0.01 & & 0.01 & 0.01 & 0.01 \\
\hline \multicolumn{7}{|c|}{ Residuals Step 1} \\
\hline Rsq & n.s. & n.s. & n.s. & 0.26 & & 0.50 \\
\hline $\mathrm{p}$ & & & & 0.02 & & 0.01 \\
\hline \multicolumn{7}{|c|}{ Residuals Step 2} \\
\hline Rsq & n.s. & n.s. & n.s. & & & \\
\hline $\mathrm{p}$ & & & & & & \\
\hline
\end{tabular}

\section{Discussion}

\subsection{Significance of budgets and anomalies}

The average $\mathrm{NEP}_{\mathrm{y}}$ at VS $\left(411 \mathrm{~g} \mathrm{C} \mathrm{m}^{-2} \mathrm{yr}^{-1}\right)$ was at the upper limit of the range found generally for temperate deciduous forests (between 160 and $390 \mathrm{~g} \mathrm{C} \mathrm{m}^{-2} \mathrm{yr}^{-1}$; Saigusa et al., 2005; Granier et al., 2008; Pilegaard et al., 2011; Froelich et al., 2015; Baldocchi et al. (2018). The value is probably not representative of a pure beech stand, as it was enhanced by the presence of conifers in the sub plot that assimilated carbon in winter and early spring, before leaf onset in the beech. Their impact could be roughly estimated by supposing that no assimilation should take place in the beech stand before leaf onset (early May) and thus the NEP during these days should be similar to those observed in January and February, when no assimilation takes place in the conifer. A rough estimate based on this assumption suggests an amplification of the uptake in the order of $80-130 \mathrm{~g} \mathrm{C} \mathrm{m}^{-2} \mathrm{yr}^{-1}$ compared to a pure beech stand. Finally, the large NEP difference before and after 2009 (107 $\mathrm{g} \mathrm{C} \mathrm{m}^{-2} \mathrm{yr}^{-1}$ ) is probably because the measurement height change modified the relative contributions of coniferous and deciduous species in the footprint.

This suggests that, despite the caution taken during data selection and treatment, the absolute NEP y values obtained at the Vielsalm site can be considered to be very sensitive to stand heterogeneity and hardly representative of a pure beech stand. The main sources of uncertainty are not linked with the eddy covariance method itself, but rather result from site heterogeneity. Such problems are probably shared by many sites as heterogeneity is a common feature of both natural and managed forests. Nevertheless, as these uncertainties are mainly systematic, anomalies are expected to be less affected by them and could be much more robust as long as the data treatment has taken these problems into account. In our case, the selection of a wind sector, the preferential use of look-up tables for data gap filling and the computation of anomalies by treating fluxes separately before and after the tower-raising constitute features essential for obtaining robust anomalies. The uncertainty on anomalies is in the order of $30 \mathrm{~g} \mathrm{C} \mathrm{m}^{-2} \mathrm{yr}^{-1}$. Even if not all uncertainty sources have been considered in our analysis, this estimate appears reasonable. The robustness of the anomaly data is corroborated further by their consistent relationships with weather and physiologic driving variables and their significant correlation with growth index (Fig. 8). Despite the relation between tree ring index and NEPA being not direct, as the former is also dependent on tree respiration and carbon allocation between the different tree organs, significant relations between these two variables can be expected, as shown by several authors (Babst et al., 2014; Teets et al., 2018).

\subsection{Lagged effects on photosynthetic capacity}

One of the most important results of this analysis is the highlighted carry-over effects on both NEPA and AA as attested by the lagged correlations between these variables and weather variables (Fig. 5). One effect is illustrated by the correlation between preceding vegetation VPD and $\mathrm{NEPA}_{\mathrm{vs}}$ (Fig. 5b), $\mathrm{AA}_{\mathrm{vs}}$ (Fig. 5e) and $\mathrm{NEPA}_{\mathrm{f}}$ (Fig. 5c); the other by the correlations between early spring precipitation or VPD and $\mathrm{AA}_{\mathrm{vs}}$ (Fig. 5e).

\subsubsection{Impact of previous year weather}

Analyses of the impacts of previous year weather conditions on NEP remain scarce (Desai, 2014; Zielis et al., 2014; Shen et al., 2016) and report very different results: as Desai (2014) suggested that moisture stress in the prior season could inhibit photosynthesis in a temperate deciduous forest, Shen et al (2016) suggested that increased precipitation on the previous year could decrease NEP of the current year in an arid savanna and Zielis et al. (2014) rather highlighted the role of minimum air temperature during the previous year spring in a subalpine forest dominated by conifers. This suggests the potential for multiple processes and different effects according to the ecosystem type.

Our observation of a negative correlation with preceding year VPD is in line with the observation by Desai (2014). It also corroborates different studies that highlight negative impacts of preceding year drought on NPP or tree growth (Granier et al., 2008; Müller-Haubold et al., 2013; Babst et al., 2014; Latte et al., 2016).

The mechanisms responsible of such delayed effects may be diverse. Bréda et al (2006) suggested that severe droughts could induce damages to tree structures due to cavitation and affect xylem plasticity (decrease of sapwood area) that could alter tree functioning for several years. In addition to these structural changes, several authors (Bréda et al., 2006; Meier and Leuschner, 2008; Müller-Haubold et al., 2013) suggest that precipitation intensity could also influence the patterns of biomass allocation to wood, leaf and fruit production in beech, low precipitations favoring storage in reproductive rather than in vegetative organs. In addition, Hertel et al (2013) suggested that, under water stress condition, beech trees could alter substantially their above-below ground carbon partitioning, favoring fine root development.

At VS, the occurrences of severe droughts are quite limited: even during the 2003 heat wave, the site was much lesser affected by drought than most of the other European sites (Ciais et al., 2005; Bréda et al., 2006; Granier et al., 2007). Even if the hypothesis of structural changes cannot be discarded, this suggests that the hypothesis of biomass allocation dependency on water conditions is more likely to act regularly: during drier years, characterized by larger VPD and lower precipitation, the biomass allocation to leaf buds would be restrained. Meier and Leuschner (2008) suggested that the water limitation is stronger in summer when leaf buds are forming so that it leads to a reduction of the bud number and thus of next season leaf number. This would explain the negative impact on NEPA of vegetation season VPD $\left(V_{\mathrm{y}-1}\right)$. No direct measurements of LAI or of leaf number were available at VS to confirm this hypothesis but it is corroborated by our observations of photosynthetic capacity (Fig. 6a and b). The present analysis also cannot determine if the biomass was allocated preferentially to root or fruits. No direct measurements of root development were available and the sole available information relative to fruit production was given at a regional scale: most intense masting years in 


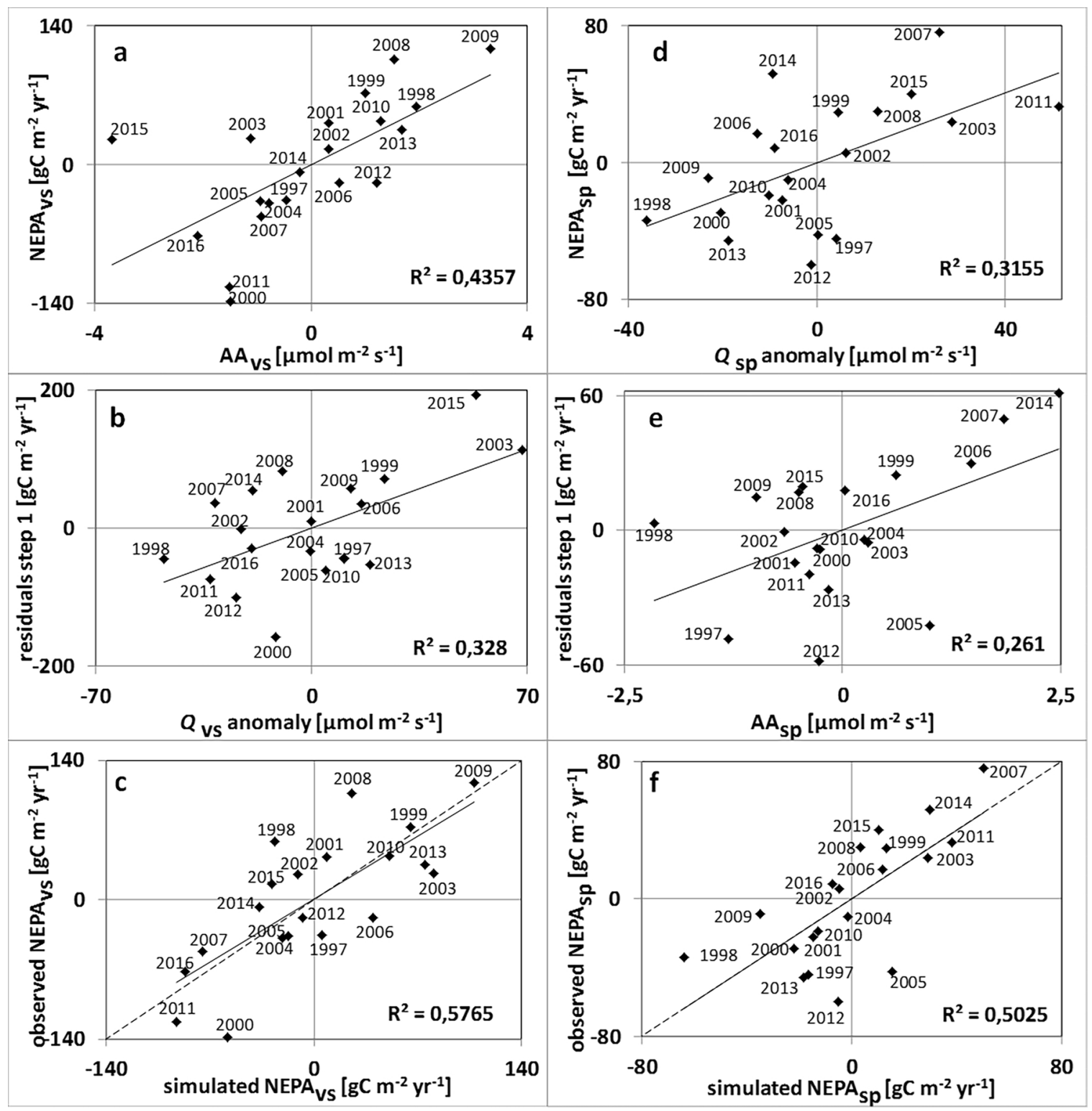

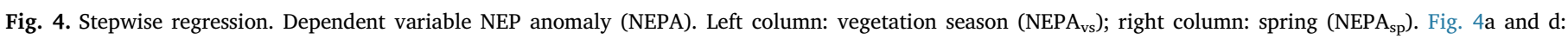

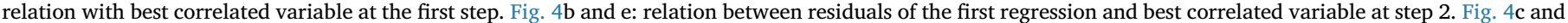
f: relation between NEPA observations and estimations with the two-variable regression. The dotted line is the 1:1 line.

Wallonia (Comptoir forestier Wallon, personal communication) were found to coincide with the lowest $\mathrm{NEP}_{\mathrm{y}}(2000,2011)$ and highest $\mathrm{NEP}_{\mathrm{y}}$ with absence of masting $(1999,2008)$. Similar observations have been made in beech forests by Pilegaard et al. (2011) in Denmark and Herbst et al. (2015) in Germany.

\subsubsection{Impact of spring drought}

A significant impact of spring drought on photosynthetic capacity was also observed (Figs. 5e and 6b). However, the correlation appears to be mainly driven by two years, one with dry spring (2015) and one with wet spring (2009). Impacts of spring drought on assimilation were found by some researchers: Latte et al. (2016) detected an impact of spring drought on tree ring growth on centennial beeches from Ardennes; Desai (2014) suggested that moisture stress at the beginning of the vegetation season inhibits photosynthesis; Müller-Haubold et al. (2013) found a positive influence of current year early summer precipitation on Net Primary Productivity and Meier and Leuschner (2008) suggested that spring water limitation could hinder leaf development. Wolf et al. (2016) explained the impact of spring drought, during the
2012 North American drought, by the early depletion of soil water resources during the warm spring that exacerbated water limitations during summer. However this explanation holds for climates characterized by a dry summer, which is not the case at VS where precipitations are present all the year. Anyway, the signal observed here is not clear enough to conclude definitely about this process.

\subsection{Drivers of $N E P_{y}$ inter-annual variability}

Contrary to many sites, no significant trend (Urbanski et al., 2007; Pilegaard et al., 2011; Froelich et al., 2015) or lagged autocorrelation (Baldocchi et al., 2018) in $\mathrm{NEP}_{\mathrm{y}}$ was found and the inter-annual $\mathrm{NEP}_{\mathrm{y}}$ standard deviation (91-95 $\mathrm{g} \mathrm{C} \mathrm{m}^{-2} \mathrm{yr}^{-1}$ ) is in the range of observations for temperate deciduous forests $\left(100 \mathrm{~g} \mathrm{C} \mathrm{m}^{-2} \mathrm{yr}^{-1}\right.$, (Baldocchi et al., 2018)).

As suggested by Desai (2014), the $\mathrm{NEP}_{\mathrm{y}}$ inter-annual variability, especially at VS, cannot be attributed to a unique cause, which explains the poor quality of single variable regression with $\mathrm{NEP}_{\mathrm{y}}$. Biotic influences, often driven by lagged weather effects, may contribute to inter- 


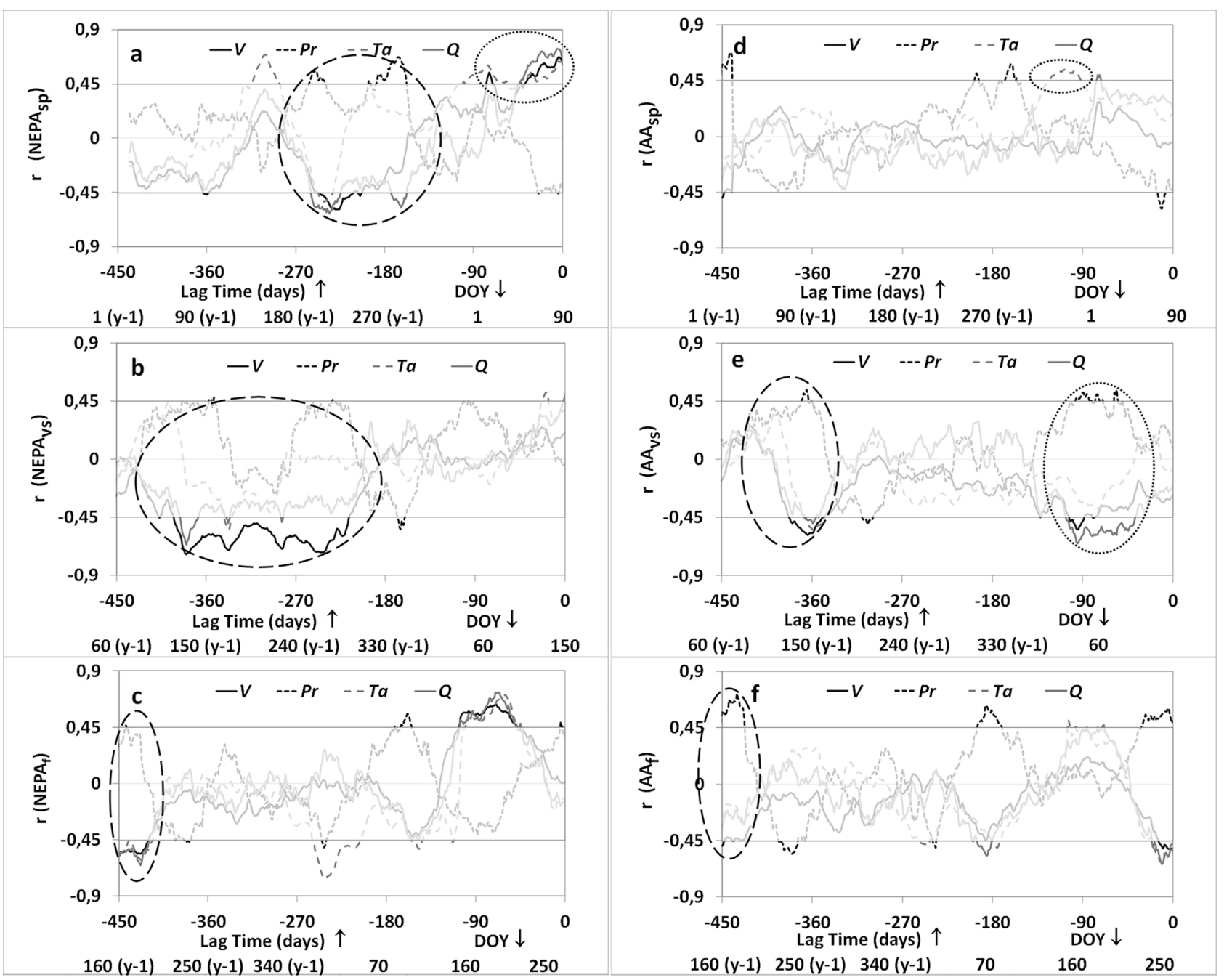

Fig. 5. Lagged correlation between periodical NEPA or photosynthetic capacity anomaly $(A A)$ and weather variables averaged over a two month moving window (the lag time represents the lag between the beginning of the considered period and the moving window; DOY represents the real date of the beginning of the moving window). Left column: NEPA during spring (Fig. 5a), vegetation season (Fig. 5b) and fall (Fig. 5c). Right column: $A A$ during spring (Fig. 5d), vegetation season (Fig. 5e) and fall (Fig. 5f). The semi-transparent frame covers non-significant correlations. V : Vapour pressure deficits; Pr : Precipitation; Ta : air temperature; Q : PAR.

annual changes.

The most intense $\mathrm{NEPA}_{\mathrm{y}}$, in $2000\left(-200 \mathrm{~g} \mathrm{~m}^{-2} \mathrm{yr}^{-1}\right)$, resulted from the bark beetle attack that reduced the leaf surface and even led to tree destruction. A comparable attack with a comparable impact on $\mathrm{NEP}_{\mathrm{y}}$ had been observed in 1998 in a Danish beech forest by Pilegaard et al. (2011). This is clearly a biotic effect but La Spina et al.(2013) also showed that such attacks are favoured by early frost events for which the trees are physiologically unprepared and which makes them more vulnerable. Such an exceptional early frost event had indeed been observed at VS in November 1998 (between DOY 321 and 343) and never reiterated during the 20 year period. This suggests that the biotic effect was in fact induced by a lagged meteorological effect. At VS, the insect attack was partly captured by our measurements and expressed by $A_{700 v s}$ and $A_{700 f}$ reductions (Fig. 4a). This reduction however was not strong enough to fully explain the $\mathrm{NEPA}_{\mathrm{y}}$ (Fig. 7). Interestingly, the effects of the insect attack did not propagate to the following years as both $\mathrm{NEP}_{\mathrm{y}}$ and $\mathrm{A}_{700 \mathrm{vs}}$ appeared unaffected in 2001 and later (Figs. 4a and 7 ), supposedly due to the subsequent leaf development in the remaining trees.

Vegetation season photosynthetic capacity $\left(A_{700 v s}\right)$ and PAR appeared to be the most important driving variables of NEP inter-annual variability at both vegetation season and whole year scales. They both explain $58 \%$ of $\mathrm{NEP}_{\mathrm{vs}}$ (Fig. $4 \mathrm{c}$ ) and $42 \%$ of $\mathrm{NEP}_{\mathrm{y}}$ variability. In particular, photosynthetic capacity variations mainly explained the larger $\mathrm{NEP}_{\mathrm{vs}}$ and $\mathrm{NEP}_{\mathrm{y}}$ in 1999, 2008 and 2009, despite average PAR conditions for the two latter years and the lower NEP in 2005, 2011 and 2016 (Fig. 4a). Here again, a biotic effect, illustrated by the $A_{700}$ variability, appears mainly driven by preceding year water conditions (Section 4.2) suggesting that the carry-over effect of preceding year water shortages would be a key driver of $\mathrm{NEP}_{\mathrm{y}}$ inter-annual variability.

Photosynthetically active radiation also impacts $\mathrm{NEP}_{\mathrm{vs}}$ and $\mathrm{NEP}_{\mathrm{sp}}$, although the former correlation is hindered by correlation with $A_{700}$ and only appears at stepwise regression step 2 . It is, however, remarkable that extreme $\mathrm{NEP}_{\mathrm{y}}$ and $\mathrm{NEP}_{\mathrm{vs}}$ corresponded more to extreme photosynthetic capacities than to extreme PAR. Especially, the sunniest years $(2003,2015)$ are not associated to the largest $\mathrm{NEP}_{\mathrm{y}}$, despite exceptional high sunlight for these years (Fig. 4b). This is due to an important $A_{700}$ reduction (Fig. 4a), possibly driven by the carry-over effects but also by drought conditions during the current vegetation season that could have induced partial stomatal closure, as observed previously (Aubinet et al., 2001). Conversely, the $\mathrm{NEP}_{\mathrm{y}}$ of the cloudiest year (1998, Fig. 4b) was not as low as expected but rather closer to the average, which could also be explained (at least partly) by the high $A_{700}$ vs for this year (Fig. 4a). 

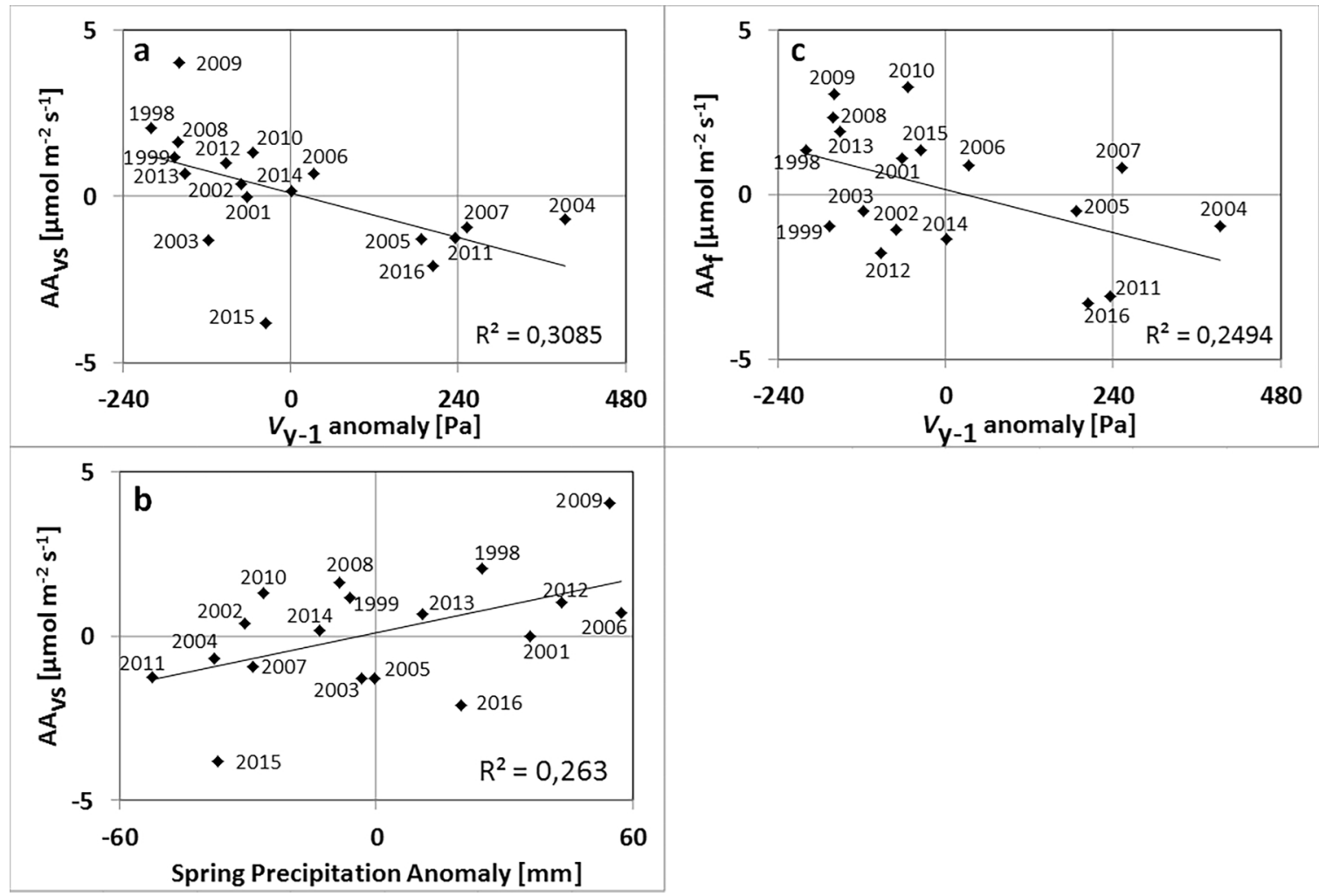

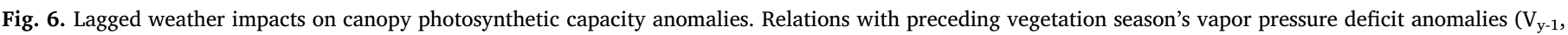
Figs. 6 a) and spring precipitation anomaly (Fig. 6b), Fig. 6c : Relation between spring AA and preceding vegetation season's vapor pressure deficit anomalies.

An impact of PAR on temperate deciduous forests $\mathrm{NEP}_{\mathrm{y}}$ inter-annual variability is not a common feature (Baldocchi et al., 2018). Although PAR appeared to be the main NEP driving factor at daily and seasonal scales, it is often not influential at the inter-annual scale. The correlation observed here may be because the VS is situated in a region where light is the most important net primary productivity limiting factor (Churkina and Running, 1998). This is corroborated by the fact that the two other deciduous forest sites where Baldocchi et al (2017) reported an impact of PAR on assimilation (i.e., Borden in Southern Ontario, Froelich et al. (2015) and Alice Holt Research Station in South Eastern England, Wilkinson et al. (2012)) are also situated in regions with similar constraints (Churkina and Running, 1998).

Winter air temperature also has a significant impact on $\mathrm{NEP}_{\mathrm{y}}$ through its impact on $\mathrm{NEP}_{\text {sp }}$ (Figs. 5a and 7a and b), high winter and early spring temperatures favoring precocious assimilation. This was especially the case in 2007, 2008 and 2014 when very mild winter conditions prevailed (temperature anomalies for Jan-Mar: $2.7^{\circ} \mathrm{C}, 1.9^{\circ} \mathrm{C}$ and $2.8^{\circ} \mathrm{C}$, respectively) while in $1997,2005,2012$ and 2013 colder temperatures (temperature anomalies for Jan-Apr: $-1.2^{\circ} \mathrm{C},-1.4^{\circ} \mathrm{C}$, $-0.5^{\circ} \mathrm{C}$ and $-1.4^{\circ} \mathrm{C}$, respectively) resulted in lower NEP precocity. In particular, it is interesting to note that as 2007 appears on the whole to be a normal year with a small $\mathrm{NEP}_{\mathrm{y}}$ anomaly, it was one of the most atypical years of the 20 year period; characterized on one hand by an exceptionally mild winter and spring, which favoured early assimilation and on the other hand by the third cloudiest vegetation season. Consequently, the small $\mathrm{NEP}_{\mathrm{y}}$ anomaly results from the compensation of two strong opposite (and independent) anomalies: positive in winter and early spring and negative during the vegetation season.

A dependence of $\mathrm{NEP}_{\mathrm{y}}$ on $\mathrm{NEP}_{\mathrm{sp}}$ (or, indirectly, on season length) was also observed at most deciduous sites (Saigusa et al., 2005; Urbanski et al., 2007; Granier et al., 2008; Pilegaard et al., 2011). Let note however that, at VS, spring assimilation operates before leaf onset in the beech and is thus more likely due to assimilation by the conifers spread in the beech sub-plot than to a precocious leaf out in the beech.
No clear impact of current year vapor pressure deficit and of dark respiration has been found, which could appear surprising. This would suggest that water stress affects carbon sequestration rather through indirect processes involving bud leaf formation than through direct processes involving stomatal closure. The absence of correlation between dark respiration and $\mathrm{NEP}_{\mathrm{y}}$ (Table 3 ) suggests, as does the whole present study, that the $\mathrm{NEP}_{\mathrm{y}}$ inter-annual variability was much more driven by assimilation than by respiration, in line with Baldocchi et al. (2018).

It is probable that, in view of the complexity of the mechanisms underlying $\mathrm{NEP}_{\mathrm{y}}$ inter-annual variability, not all causes have been identified. In particular, over five years, the residuals of the relation between $\mathrm{NEP}_{\mathrm{y}}$ and driving variable anomalies remained larger than their uncertainty (Fig. 7). Among the different possible causes of discrepancy, we identified a possible impact of fall NEP (2000, 2006, 2015), uncertainties in the $A_{700}$ estimate due to insufficient data (2013), or the difficulty of statistical regressions to account for the exceptional character of an event (the insect attack in 2000). No plausible explanation was found for the fifth year (1998).

Finally, the study did not address the question of management. The forest underwent several thinning and tree cut events during the observation period. However, no information about the exact dates, location and thinning intensity were available, making this analysis impossible at VS. It is thus possible that some of the unexplained anomalies are due to management, although Granier et al. (2008), who studied another beech forest, showed that the thinning impact was limited.

\section{Conclusions}

This study suggests that uncertainties affecting carbon budgets at heterogeneous sites may be large and do not directly result from the eddy covariance method but from the heterogeneity itself. Uncertainties linked to the eddy covariance method (random 


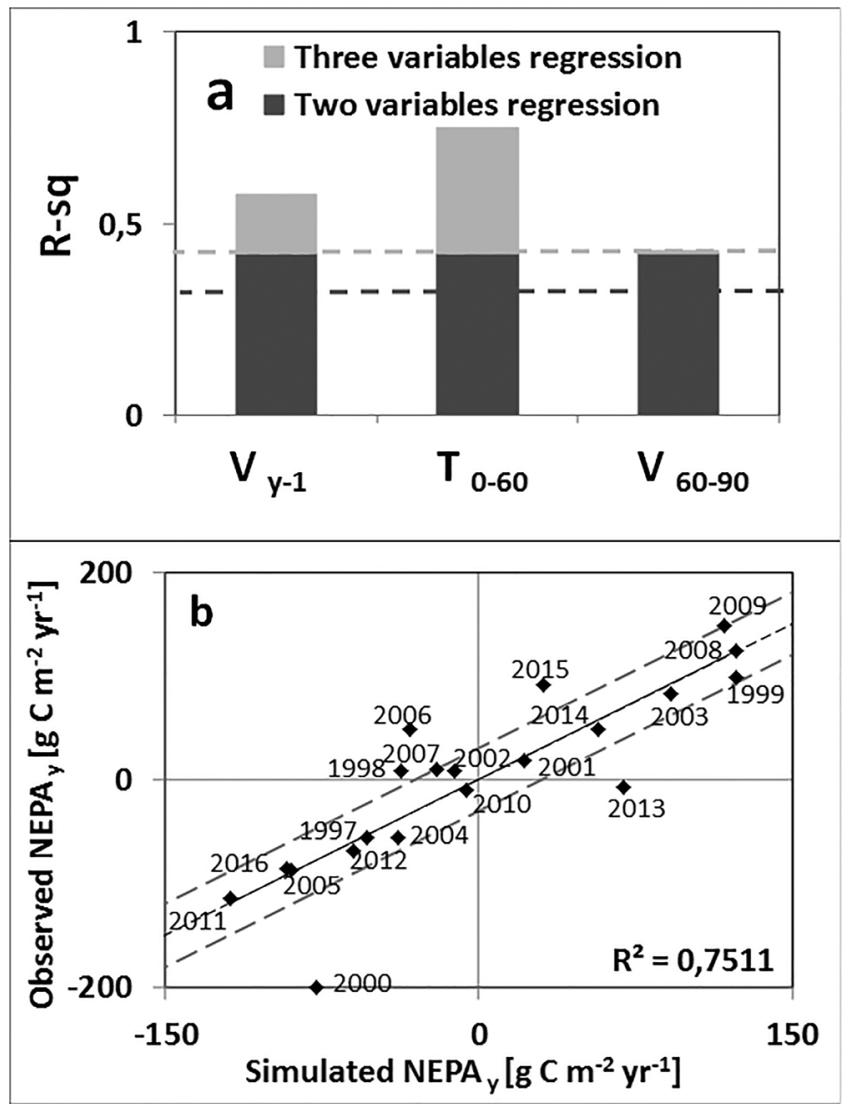

Fig. 7. Main sequestration inter-annual variability drivers. Fig. 7a : correlation coefficients of two variables $\left(A A_{\mathrm{vs}}, Q_{\mathrm{vs}}\right)$ and three variables regressions the third variable is either $V_{\mathrm{y}-1}, T_{0-60}$ or $V_{60-90}$, respectively). The dotted lines indicate the significance threshold $(\mathrm{p}=0.05)$ for each regression. Fig. $7 \mathrm{~b}$ : Best three variable regression: relation between $\mathrm{NEPA}_{y}$ observations and simulations based on $A A_{\mathrm{vs}}, Q_{\mathrm{vs}}$ and T 0-60. The black dotted line is the 1:1 line. The grey dotted lines represent the $\pm 30 \mathrm{~g} \mathrm{C} \mathrm{m}^{-2} \mathrm{yr}^{-1}$ range, corresponding to the average uncertainty affecting anomalies.

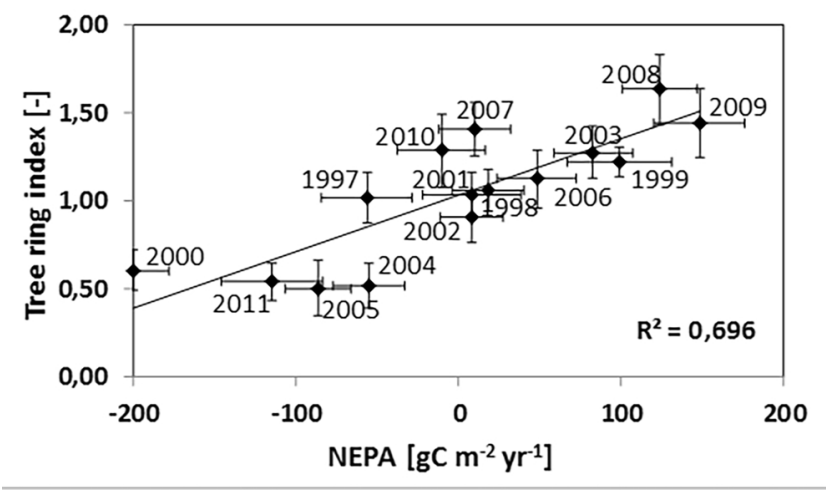

Fig. 8. Relation between $\mathrm{NEPA}_{\mathrm{y}}$ and tree ring index computed on the basis of wood increment. Vertical error bars represent the standard error of the tree index ring mean and the horizontal bar, the uncertainty computed in Table 1.

variability, $u_{*}$ correction, frequency correction, data gap filling) only amounted to 7-11 $\mathrm{g} \mathrm{C} \mathrm{m}^{-2} \mathrm{yr}^{-1}$ for the long-term budgets, while uncertainty linked to heterogeneity may be up to several hundreds of $\mathrm{g} \mathrm{C}$ $\mathrm{m}^{-2} \mathrm{yr}^{-1}$. The tower height increase at VS, from 40 to $52 \mathrm{~m}$ in 2009 , induced a $100 \mathrm{~g} \mathrm{C} \mathrm{m}^{-2} \mathrm{yr}^{-1}$ difference in the $\mathrm{NEP}_{\mathrm{y}}$ and the presence of isolated conifers in the beech subplot induced a bias for $\mathrm{NEP}_{\mathrm{y}}$, estimated to about $80-130 \mathrm{~g} \mathrm{C} \mathrm{m}^{-2} \mathrm{yr}^{-1}$ compared to a pure beech stand.
If this questions the accuracy of heterogeneous forest annual budgets, this is not the case with yearly anomalies that are much more robust, provided a careful treatment is developed. In the present case, the treatment included the selection of a wind sector focusing on the target species (beech sub plot), the use of a data gap filling procedure centered on look up tables in order to avoid a biased selection of meteorological conditions and the computation of yearly anomalies considering measurement height changes during the experiment. As a result, uncertainties for anomalies (mainly resulting from eddy flux measurement and computation) are estimated to amount to about $30 \mathrm{~g}$ $\mathrm{C} \mathrm{m}^{-2} \mathrm{yr}^{-1}$. Even if we cannot guarantee that all impacts of stand heterogeneity were removed from anomaly estimates (specifically, the $\mathrm{NEP}_{\mathrm{sp}}$ inter-annual variability is still suspected to be linked to conifer activity), a sufficiently robust data set was obtained in order to highlight causes of $\mathrm{NEP}_{\mathrm{y}}$ inter-annual variability.

The causes of $\mathrm{NEP}_{\mathrm{y}}$ inter-annual variability were found to be multiple, but the main causes were carry-over effects. The effects of water limitations during the preceding vegetation season were especially apparent in 2004, 2005, 2007, 2011 and 2016 while the effect due to the early frost, in November 1998 was the 2000 bark beetle attack that provoked the largest NEP deficit of the 20 year period. Both effects significantly affected the photosynthetic capacity and NEP . To our knowledge, such legacy effects have not been reported in long-term eddy covariance studies and it would be interesting to test their impact at other sites.

Other causes of inter-annual variability were PAR during the vegetation season and winter temperature.

\section{Acknowledgements}

Over the twenty measurement years, the research has been supported by the European Commission, (Projects EUROFLUX - contract ENV4-CT95-0078; CARBOEUROFLUX - contract EVK2-CT-1999- 00032 and CarboEurope IP - contract GOCE-CT-2003-505572), and the Belgian Fonds National de la Recherche Scientifique (Convention 9.4582.95F, Crédit aux chercheurs 1.5.095.05). The project is presently funded by the Service Public de Wallonie (Project ICOS -Wallonia, convention 1217769). We thanks the editor and two anonymous reviewers for fruitful comments.

\section{Appendix A. Supplementary data}

Supplementary material related to this article can be found, in the online version, at doi:https://doi.org/10.1016/j.agrformet.2018.07. 024.

\section{References}

Ameriflux, 2018. Ameriflux Web Site. (Accessed on 8 February 2018. http://ameriflux. lbl.gov/.

Aubinet, M., Grelle, A., Ibrom, A., Rannik, U., Moncrieff, J., Foken, T., Kowalski, A.S., Martin, P., Berbigier, P., Bernhofer, C., Clement, R., Elbers, J., Granier, A., Grunwald, T., Morgenstern, K., Pilegaard, K., Rebmann, C., Snijders, W., Valentini, R., Vesala, T., 2000. Estimates of the annual net carbon and water exchange of forests: the Euroflux methodology. Adv. Ecol. Res. 30, 113-175.

Aubinet, M., Chermanne, B., Vandenhaute, M., Longdoz, B., Laitat, E., Yernaux, M., 2001. Long term carbon dioxide exchange above a mixed forest in the Belgian Ardennes. Agric. For. Meteorol. 108 (4), 293-315.

Aubinet, M., Heinesch, B., Perrin, D., Moureaux, C., 2005. Discriminating net ecosystem exchange between different vegetation plots in a heterogeneous forest. Agric. For. Meteorol. 132 (3-4), 315-328.

Aubinet, M., Vesala, T., Papale, D., 2012. Eddy Covariance: A Practical Guide to Measurement and Data Analysis. Springer.

Babst, F., Bouriaud, O., Papale, D., Gielen, B., Janssens, I.A., Nikinmaa, E., Ibrom, A., Wu, J., Bernhofer, C., Köstner, B., Grünwald, T., Seufert, G., Ciais, P., Frank, D., 2014. Above-ground woody carbon sequestration measured from tree rings is coherent with net ecosystem productivity at five eddy-covariance sites. New Phytol. 201, 1289-1303.

Baldocchi, D.D., Falge, E., Gu, L., Olson, R., Hollinger, D., Running, S., Anthoni, P., Bernhofer, C., Davis, K., Evans, R., Fuentes, J., Goldstein, A., Katul, G., Law, B., Lee, X., Malhi, Y., Meyers, T., Munger, W., Oechel, W., Paw U, K.T., Pilegaard, K., Schmid, 
H.P., Valentini, R., Verma, S., Vesala, T., Wilson, K., Wofsy, S., 2001. FLUXNET: a new tool to study the temporal and spatial variability of ecosystem-scale carbon dioxide, water vapor, and energy flux densities. Bull. Am. Meteorol. Soc. 82 (11), 2415-2434.

Baldocchi, D., Chu, H., Reichstein, M., 2018. Inter-annual variability of net and gross ecosystem carbon fluxes: a review. Agric. For. Meteorol. 249, 520-533. https://doi. org/10.1016/j.agrformet.2017.05.015.

Becker, M., Nieminen, T.M., Geremia, F., 1994. Short-term variations and long-term changes in oak productivity in northeastern France. The role of climate and atmospheric CO2. Annales des Sciences Forestieres 51 (5), 477-492.

Bréda, N., Huc, R., Granier, A., Dreyer, E., 2006. Temperate forest trees and stands under severe drought: a review of ecophysiological responses, adaptation processes and long-term consequences. Ann. For. Sci. 63, 625-644.

Bunn, A.G., 2010. Statistical and visual crossdating in R using the dplR library. Dendrochronologia 28 (4), 251-258. https://doi.org/10.1016/j.dendro.2009.12.001. Available at:.

Campioli, M., Gielen, B., Göckede, M., Papale, D., Bouriaud, O., Granier, A., 2011. Temporal variability of the NPP-GPP ratio at seasonal and interannual time scales in a temperate beech forest. Biogeosciences 8, 2481-2492.

Churkina, G., Running, S.W., 1998. Contrasting climatic controls on the estimated productivity of global terrestrial biomes. Ecosystems 1 (2), 206-215.

Ciais, P., Reichstein, M., Viovy, N., Granier, A., Ogee, J., Allard, V., Aubinet, M., Buchmann, N., Bernhofer, C., Carrara, A., Chevallier, F., De Noblet, N., Friend, A., Friedlingstein, P., Grunwald, T., Heinesch, B., Keronen, P., Knohl, A., Krinner, G., Loustau, D., Manca, G., Matteucci, G., Miglietta, F., Ourcival, J., Papale, D., Pilegaard, K., Rambal, S., Seufert, G., Soussana, J., Sanz, M., Schulze, E., Vesala, T., Valentini, R., 2005. Europe-wide reduction in primary productivity caused by the heat and drought in 2003. Nature 437 (7058), 529-533.

De Ligne, A., 2016. High Frequency Correction Method for CO2 and Water Vapour Fluxes: An Application on Walloon Terrestrial Observatorties Data. Technical Report. Gembloux Agro-Bio Tech. http://hdl.handle.net/2268/187430.

Desai, A.R., 2014. Influence and predictive capacity of climate anomalies on daily to decadal extremes in canopy photosynthesis. Photosyn. Res. 119 (1-2), 31-47.

Foken, Th., Wichura, B., 1996. Tools for quality assessment of surface-based flux measurements. Agric. For. Meteorol. 78, 83-105.

Foken, T., Leuning, R., Oncley, S., Mauder, M., Aubinet, M., 2012. Corrections and data quality control. Eddy Covariance: A Practical Guide to Measurements and Data Analysis. Springer, Verlag, pp. 85-132.

Froelich, N., Croft, H., Chen, J.M., Gonsamo, A., Staebler, R.M., 2015. Trends of carbon fluxes and climate over a mixed temperate-boreal transition forest in southern Ontario, Canada. Agric. For. Meteorol. 211, 72-84.

Granier, A., Reichstein, M., Breda, N., Janssens, I., Falge, E., Ciais, P., Grunwald, T., Aubinet, M., Berbigier, P., Bernhofer, C., Buchmann, N., Facini, O., Grassi, G., Heinesch, B., Ilvesniemi, H., Keronen, P., Knohl, A., Kostner, B., Lagergren, F., Lindroth, A., Longdoz, B., Loustau, D., Mateus, J., Montagnani, L., Nys, C., Moors, E., Papale, D., Peiffer, M., Pilegaard, K., Pita, G., Pumpanen, J., Rambal, S., Rebmann, C., Rodrigues, A., Seufert, G., Tenhunen, J., Vesala, I., Wang, Q., 2007. Evidence for soil water control on carbon and water dynamics in European forests during the extremely dry year: 2003. Agric. For. Meteorol. 143 (1-2), 123-145.

Granier, A., Breda, N., Longdoz, B., Gross, P., Ngao, J., 2008. Ten years of fluxes and stand growth in a young beech forest at Hesse, North-eastern France. Ann. For. Sci. 65 (7). https://doi.org/10.1051/forest:2008052. 704.

Guay, R., Gagnon, R., Morin, H., 1992. A new automatic and interactive tree-ring measurement system based on a line scan camera. For. Chron. 68 (1), 138-141.

Herbst, M., Mund, M., Tamrakar, R., Knohl, A., 2015. Differences in carbon uptake and water use between a managed and an unmanaged beech forest in central Germany. For. Ecol. Manage. 355, 101-108.

Hertel, D., Strecker, T., Müller-Haubold, H., Leuschner, C., 2013. Fine root biomass and dynamics in beech forests across a precipitation gradient-is optimal resource partitioning theory applicable to water-limited mature trees? J. Ecol. 101 (5), 1183-1200. https://doi.org/10.1111/ 1365-2745.12124.

Hurdebise, Q., Heinesch, B., De Ligne, A., Vincke, C., Aubinet, M., 2017. Impact of canopy aerodynamic distance spatial and temporal variability on long term eddy covariance measurements. Agric. For. Meteorol. 247, 131-138.

ICOS, 2018. ICOS Web Site. Consulted on 8 Feb 2018. https://www.icos-ri.eu/?

JCGM, 2008. Evaluation of Measurement Data - Guide to the Expression of Uncertainty in Measurement, Working Group 1 of the Joint Committee for Guides in Metrology. Bur. Intl. Poids et Mesures (Sèvres, France). .

Kolle, O., Rebmann, C., 2007. Eddysoft - Documentation of a Software Package to Acquire and Process Eddy Covariance Data. Technical Reports 10. Max-Planck-Institut für Biogeochemie, pp. 88.

La Spina, S., De Canniere, C., Dekri, A., Grégoire, J., 2013. Frost increases beech susceptibility to scolytine ambrosia beetles. Agric. For. Entomol. 15, 157-167.

Latte, N., Lebourgeois, F., Claessens, H., 2016. Growth partitioning within beech trees (Fagus sylvatica L.) varies in response to summer heat waves and related droughts. Trees - Struct. Funct. 30 (1), 189-201.

Le Quéré, C., Andrew, R., Friedlingstein, P., Sitch, S., Pongratz, J., Manning, A., Korsbakken, J.I., Peters, G., Canadell, J., Jackson, R., Boden, T., Tans, P., et al., 2018. Global carbon budget 2017. Earth Syst. Sci. Data Discuss. 10, 405-448.

Lebourgeois, F., Mérian, P., 2012. Principes et méthodes de la dendrochronologie. Master. Nancy, France. < cel-01627048 > . https://hal.archives-ouvertes.fr/cel-01627048.

Malardel, S., 2005. Fondamentaux de Météorologie, Cépaduès, Météo France. Toulouse, France. .

Mauder, M., Cuntz, M., Drüe, C., Graf, A., Rebmann, C., Schmid, H.P., Schmidt, M., Steinbrecher, R., 2013. A strategy for quality and uncertainty assessment of long-term eddy-covariance measurements. Agric. For. Meteorol. 169, 122-135.
Meier, I.C., Leuschner, C., 2008. Leaf size and leaf area index in Fagus sylvatica forests: competing effects of precipitation, temperature, and nitrogen availability. Ecosystems 11, 655-669.

Mérian, P., 2013. Outils et méthodes POINTER et DENDRO: deux applications sous R pour l' analyse de la réponse des arbres au climat par approche dendroécologique. Rev. For. Fr. LXIV 6-2012. pp. 789-798.

Moffat, A.M., Papale, D., Reichstein, M., Hollinger, D.Y., Richardson, A.D., Barr, A.G., Beckstein, C., Braswell, B.H., Churkina, G., Desai, A.R., Falge, E., Gove, J.H., Heimann, M., Hui, D., Jarvis, A.J., Kattge, J., Noormets, A., Stauch, V.J., 2007. Comprehensive comparison of gapfilling techniques for eddy covariance net carbon fluxes. Agric. For. Meteorol. 147, 209-232. https://doi.org/10.1016/j.agrformet. 2007.08.011. ISSN: 0168-1923.

Müller-Haubold, H., Hertel, D., Seidel, D., Knutzen, F., Leuschner, C., 2013. Climate responses of aboveground productivity and allocation in Fagus sylvatica: a transect study in mature forests. Ecosystems 16 (8), 1498-1516.

Nicolini, G., Aubinet, M., Feigenwinter, C., Heinesch, B., Lindroth, A., Mamadou, O., Moderow, U., Mölder, M., Montagnani, L., Rebmann, C., Papale, D., 2018. Impact of $\mathrm{CO} 2$ storage flux sampling uncertainty on net ecosystem exchange measured by eddy covariance. Agric. For. Meteorol. 248, 228-239.

Pilegaard, K., Ibrom, A., Courtney, M., Hummelshoj, P., Jensen, N., 2011. Increasing net CO2 uptake by a Danish beech forest during the period from 1996 to 2009. Agric. For. Meteorol. 151 (7), 934-946. https://doi.org/10.1016/j.agrformet.2011.02.013. Available at:.

Rebmann, C., Kolle, O., Heinesch, B., Queck, R., Ibrom, A., Aubinet, M., 2012. Data acquisition and flux calculations. Eddy Covariance: A Practical Guide to Measurements and Data Analysis. Springer, Verlag, pp. 59-84.

Reichstein, M., Falge, E., Baldocchi, D., Papale, D., Aubinet, M., Berbigier, P., Bernhofer, C., Buchmann, Gilmanov, T., Granier, A., Gr" unwald, T., Havrankova, K., Ilvesniemi, H., Janous, D., Knohl, A., Laurila, T., Lohila, A., Loustau, D., Matteucci, G., Meyers, T., Miglietta, F., Ourcival, J.M., Pumpanen, J., Rambal, S., Rotenberg, E., Sanz, M., Tenhunen, J., Seufert, G., Vaccari, F., Vesala, T., Yakir, D., Valentini, R., 2005. On the separation of net ecosystem exchange into assimilation and ecosystem respiration: review and improved algorithm. Glob. Change Biol. Bioenergy 11, 1424-1439.

Richardson, A.D., Hollinger, D.Y., Burba, G.G., Davis, K.J., Flanagan, L.B., Katul, G.G., Munger, W.J., Ricciuto, D.M., Stoy, P.C., Suyker, A.E., Verma, S.B., Wofsy, S.C., 2006. A multi-site analysis of random error in tower-based measurements of carbon and energy fluxes. Agric. For. Meteorol. 136, 1-18.

Richardson, A.D., Hollinger, D.Y., Aber, J.D., Ollinger, S.V., Braswell, B.H., 2007. Environmental variation is directly responsible for short- but not long-term variation in forest-atmosphere carbon exchange. Glob. Change Biol. 13 (4), 788-803.

Richardson, A.D., Aubinet, M., Barr, A.G., Hollinger, D.Y., Ibrom, A., Lasslop, G., Reichstein, M., 2012. Uncertainty quantification. In: Aubinet, M., Vesala, T., Papale, D. (Eds.), Eddy Covariance: A Practical Guide to Measurement and Data Analysis. Springer, Dordrecht, pp. 173-210.

Rohner, B., Weber, P., Thürig, E., 2016. Bridging tree rings and forest inventories: how climate effects on spruce and beech growth aggregate over time. For. Ecol. Manage. 360, 159-169.

Saigusa, N., Yamamoto, S., Murayama, S., Kondo, H., 2005. Inter-annual variability of carbon budget components in a cooltemperate deciduous forest in Japan (Takayama, AsiaFlux). Phyton-Annales Rei Botanicae 45 (4), 81-88.

Schulze, E.D., Ciais, P., Luyssaert, S., Schrumpf, M., Janssens, I.A., Thiruchittampalam, P., Theloke, M., Saurat, M., Bringezu, S., Lel, I., Eveld, J., Lohila, A., Rebmann, C., Jung, M., Bastviken, D., Abr il, G., Grassi, G., Leip, A., Freibauer, A., Kutsch, W., Don, A., Nieschulze, A., Börner, A., Gash, J., Dolman, A.J., 2010. The European carbon balance. Part 4. Integration of carbon and other trace gase fluxes. Glob. Change Biol. 16, 1451-1469.

Shen, W., Jenerette, G.D., Hui, D., Scott, R.L., 2016. Precipitation legacy effects on dryland ecosystem carbon fluxes: direction, magnitude and biogeochemical carryovers. Biogeosciences 13, 425-439.

Soubie, R., 2014. Evaluation de l'évapotranspiration réelle, de ses composantes et de sa régulation dans un peuplement composé de hêtres et de douglas: analyse comparative de l'effet espèce et des méthodes d'évaluation. Université catholique de Louvain.

Soubie, R., Heinesch, B., Granier, A., Aubinet, M., Vincke, C., 2016. Agricultural and Forest Meteorology Evapotranspiration assessment of a mixed temperate forest by four methods: eddy covariance, soil water budget, analytical and model. Agric. For. Meteorol. 228-229, 191-204. https://doi.org/10.1016/j.agrformet.2016.07.001. Available at:.

Starr, G., Staudhammer, C.L., Wiesner, S., Kunwor, S., Loescher, H.W., Baron, A.F., Whelan, A., Mitchell, R.J., Boring, L., 2016. Carbon dynamics of Pinus palustris ecosystems following drought. Forests 7 (5), 98.

Teets, A., Fraver, S., Hollinger, D.Y., Weiskittel, A.R., Seymour, R.S., Richardson, A.D. 2018. Linking annual tree growth with eddy-flux measures of net ecosystem productivity across twenty years of observation in a mixed conifer forest. Agric. For. Meteorol. 249, 479-487.

Urbanski, S., Barford, C., Wofsy, S., Kucharik, C., Pyle, E., Budney, J., McKain, K., Fitzjarrald, D., Czikowsky, M., Munger, J.W., 2007. Factors controlling CO2 exchange on timescales from hourly to decadal at Harvard Forest. J. Geophys. Res. Biogeosci. $112(2), 1-25$.

Vacchiano, G., Hacket-Pain, A., Turco, M., Motta, R., Maringer, J., Conedera, M., Drobyshev, I., Ascoli, D., 2017. Spatial patterns and broad-scale weather cues of beech mast seedling in Europe. New Phytol. 215 (2), 595-608. https://doi.org/10. 1111 /nph. 14600.

Valentini, R., Matteucci, G., Dolman, A., Schulze, E., Rebmann, C., Moors, E., Granier, A., Gross, P., Jensen, N., Pilegaard, K., Lindroth, A., Grelle, A., Bernhofer, C., Grunwald, T., Aubinet, M., Ceulemans, R., Kowalski, A., Vesala, T., Rannik, U., Berbigier, P., Loustau, D., Guomundsson, J., Thorgeirsson, H., Ibrom, A., Morgenstern, K., Clement, 
R., Moncrieff, J., Montagnani, L., Minerbi, S., Jarvis, P., 2000. Respiration As the main determinant of carbon balance in European forests. Nature 404 (6780), 861-865.

van Gorsel, E., Cleverly, J., Beringer, J., 2018. Preface: OzFlux: a network for the study of ecosystem carbon and water dynamics across Australia and New Zealand. Biogeosciences 15, 349-352.

Vincke, C., De Ligne, A., Manise, T., 2016. Documentation on the Terrestrial Observatory of Viesalm (OTV). Technical Report. Gembloux Agro-Bio Tech. http://hdl.handle. net/2268/205628.

Wilkinson, M., Eaton, E.L., Broadmeadow, M.S.J., Morison, J.I.L., 2012. Inter-annual variation of carbon uptake by a plantation oak woodland in south-eastern England. Biogeosciences 9 (12), 5373-5389.
Wolf, S., Keenan, T., Fischer, J.B., Baldocchi, D., Desai, A., Richardson, A., Scott, R., Law, B., Litvak, M., Brunsell, N., Peters, W., Laan-Luijkx, Van der, 2016. Warm spring reduced carbon cycle impact of the 2012 SU summer drought. PNAS 113 (21), 5880-5885.

Yamamoto, S., Saigusa, N., Gamo, M., Fujinuma, Y., Inoue, G., Hirano, T., 2005. Findings through the AsiaFlux network and a view toward the future. J. Geogr. Sci. 15 (2), 142-148.

Zielis, S., Etzold, S., Zweifel, R., Eugster, W., Haeni, M., Buchmann, N., 2014. NEP of a Swiss subalpine forest is significantly driven not only by current but also by previous year's weather. Biogeosciences 11, 1627-1635. https://doi.org/10.5194/bg-111627-2014. 